\title{
A Critical Period of Protein Kinase Activity After Tetanic Stimulation Is Required for the Induction of Long-term Potentiation
}

Kimberly M. Huber, Michael D. Mauk, Chad Thompson, and Paul T. Kelly ${ }^{1}$

Department of Neurobiology and Anatomy

University of Texas Medical School

Houston, Texas 77225

\section{Abstract}

A critical period of protein kinase activity required for the induction of long-term potentiation (LTP) was determined in area CA1 of hippocampal slices using the broad-range and potent protein kinase inhibitors K-252a and staurosporine. As reported previously, K-252a and staurosporine blocked LTP induction when applied before, during, and after high-frequency stimulation (HFS). In contrast, K-252a did not block LTP when applied only before and during HFS and washed out immediately after HFS. K-252a and staurosporine both attenuated LTP magnitude when applied immediately after or as late as $5 \mathrm{~min}$ after HFS. However, K-252a applications beginning $30-45 \mathrm{~min}$ after HFS did not affect LTP expression significantly. K-252a had no detectable effect on isolated $N$-methyl-D-aspartate (NMDA) receptor-mediated EPSPs but significantly inhibited the in situ phosphorylation of specific hippocampal proteins (synapsin I, MARCKS, and B-50). In addition, K-252a attenuated $4 \beta$-phorbol12,13-dibutyrate (PDBu)-enhanced synaptic transmission. Our results indicate that there is a critical period of protein kinase activity required for LTP induction that extends for $\sim 20 \mathrm{~min}$ after HFS. In addition, our results suggest that protein kinase activity during and immediately after HFS is not sufficient for LTP induction. These results provide new information about the mechanisms that underlie LTP induction and expression and

\footnotetext{
${ }^{1}$ Corresponding author.
}

provide evidence for persistent and/or $\mathrm{Ca}^{2+}$-independent protein kinase activity involvement in LTP

\section{Introduction}

Long-term potentiation (LTP) is generally considered to be a cellular model of learning and memory and was first identified in the hippocampus (Bliss and Lømo 1973). LTP in area CA1 of the hippocampus can be induced by a high-frequency, or tetanic, stimulation (HFS) of presynaptic fibers and is dependent on postsynaptic $\mathrm{Ca}^{2+}$ increases mediated by $N$-methyl-D-aspartate (NMDA) receptors (Collingridge et al. 1983; Lynch et al. 1983). The activation of $\mathrm{Ca}^{2+}$-dependent protein kinases has been implicated as a critical secondary step in LTP induction (Malinow et al. 1988). Many studies have utilized specific and broad-range protein kinase inhibitors to demonstrate that kinases are required during HFS or the induction phase of LTP (for reviews, see Meffert et al. 1991; Bliss and Collingridge 1993). Postsynaptic injection of specific inhibitors of protein kinase $\mathrm{C}$ (PKC) or $\mathrm{Ca}^{2+}$ / calmodulin-dependent protein kinase II (CaMKII) prior to HFS blocks LTP induction (Malenka et al. 1989; Malinow et al. 1989). Once activated by a $\mathrm{Ca}^{2+} /$ cofactor complex, PKC and CaMKII both have the ability to convert into a $\mathrm{Ca}^{2+}$-independent or constitutively active enzyme (Kishimoto et al. 1983; Miller and Kennedy 1986; Kikkawa et al. 1989). A prominent theory concerning the molecular mechanisms underlying LTP expression proposes the generation of $\mathrm{Ca}^{2+}$-independent and persistently active protein kinases that are responsible for the expression or maintenance of LTP (Malinow et al. 1988; for a recent review, see Lisman 1994). In support of this hypothesis, increases in $\mathrm{Ca}^{2+}$-independent PKC and CaMKII ac-

LEARNING \& MEMORY 2:81-100 ๔ 1995 by Cold Spring Harbor Laboratory Press ISSN1072-0502/95 $\$ 5.00$

$$
\begin{array}{lllllllllllllll}
L & E & A & R & N & I & N & G & \begin{array}{l}
\boldsymbol{Q} \\
81
\end{array} & M & E & M & O & R & Y
\end{array}
$$


tivity in hippocampal homogenates have been correlated with LTP (Fukanaga et al. 1993; Klann et al. 1993; Sacktor et al. 1993). However, knowledge of the temporal sensitivity of LTP maintenance or expression to protein kinase inhibitors is limited and controversial. Malinow and colleagues (1988) initially demonstrated that the extracellular application of the broad-range protein kinase inhibitor 1-(5-isoquinolinylsulfonyl)-2-methylpiperazine (H-7) could reversibly attenuate LTP expression without affecting nonpotentiated or basal synaptic transmission. However, subsequent studies (Corradetti et al. 1989; Muller et al. 1990; Leahy and Vallano 1991; Waxham et al. 1993) were unable to detect any specific attenuation of potentiated pathways by $\mathrm{H}-7$ and found that nonpotentiated or basal synaptic transmission was also attenuated. Therefore, these results suggest that persistent protein kinase activity is not responsible for LTP expression (Muller et al. 1990) and/or regulates transmission at both potentiated and nonpotentiated synapses (Corradetti et al. 1989; Waxham et al. 1993). In addition, $\mathrm{H}-7$ has been reported to have nonspecific (kinase-independent) effects on NMDA receptor activity (Amador and Dani 1991). More recent studies (Reymann et al. 1990; Matthies et al. 1991; Muller et al. 1992) have utilized a new class of protein kinase inhibitors (K-252b and staurosporine), which are potent, membranepermeable, broad-range kinase inhibitors that do not possess the reported nonspecific affects of H-7. Although consistent results were obtained indicating that protein kinase activities are required during LTP induction (Denny et al. 1990; Reymann et al. 1990, Matthies et al. 1991; Muller et al. 1992), there have been conflicting results on the effects of these inhibitors on LTP expression (see Denny et al. 1990; Matthies et al. 1991). Wang and Feng (1992) were successful in demonstrating that the postsynaptic injection of a combination of PKC inhibitors, the pseudosubstrate inhibitory peptide PKC ${ }_{19-31}$ and polymixin B, specifically attenuated potentiated pathways, whereas other studies have found that the postsynaptic injection of $\mathrm{H}-7$ (Huang et al. 1992), $\mathrm{PKC}_{19-31}$, or a peptide inhibitor of CaMKII (CaMKII $273-302$ ) did not impact on LTP expression (Malinow et al. 1989). Therefore, the time course of protein kinase activity required for the induction and expression of LTP has remained controversial.

We have examined the time course of protein kinase activity required for LTP using the potent, membrane-permeable, broad-range protein kinase inhibitors K-252a (Kase et al. 1986; Hashimoto et al. 1991) and staurosporine (Tamaoki, et al. 1986). K-252a inhibits protein kinases by competing with ATP, and staurosporine acts by binding to the catalytic domain of PKC and CaMKII but is not competitive with ATP (Rüegg and Burgess 1989). Consequently, these inhibitors block both the $\mathrm{Ca}^{2+}$-dependent and -independent activities of PKC and CaMKII and are at least 500 times more potent than H-7 (Kase et al. 1986; Tamaoki et al. 1986; Hashimoto et al. 1991). We have determined inhibitor concentrations that specifically attenuate potentiated pathways and not basal synaptic transmission, and analyzed both the efficacy and kinetics of inhibitor actions by examining their ability to inhibit the in situ phosphorylation of hippocampal proteins (Yip and Kelly 1989) or block the enhancement of synaptic transmission induced by the PKC activator 4 $\beta$-phorbol-12,13dibutyrate (PDBu; Reymann et al. 1988).

It is generally believed that the critical period of kinase activity required for LTP induction occurs during the delivery of induction stimuli (i.e., HFS) and immediately thereafter. Results from $\mathrm{Ca}^{2+}$ imaging and photolyzable $\mathrm{Ca}^{2+}$ chelator experiments suggest that second-messenger production and protein kinase activation occur within seconds after induction stimuli (Regehr et al. 1989; Müller and Connor 1991; Malenka et al. 1992). However, most studies have only examined the involvement of protein kinases during or 30120 min after induction stimuli. A clearer resolution of the time course of protein kinase activity required for LTP will be instrumental in identifying the roles of phosphorylation/dephosphorylation in LTP induction and expression. We have systematically examined the temporal requirement for protein kinase activity during LTP induction and demonstrate that the requirement for protein kinase activity is not limited to the period during and immediately after HFS. Rather, our data suggest a critical period of protein kinase activity occurs 5-20 min after HFS and is required for LTP induction. In addition, our results indicate that protein kinase activity during and immediately after HFS is not sufficient to induce LTP. These data suggest that the distinction between LTP induction and expression may not simply be events that occur during and immediately after HFS versus hours after LTP induction. Our results support the hypothesis that persistent protein kinase activity, possibly $\mathrm{Ca}^{2+}$ independent, is required for LTP induction.

$$
\text { ….... }
$$




\section{Materials and methods}

\section{TISSUE PREPARATION}

Hippocampal slices were prepared from pentobarbital-anesthetized ( $50 \mathrm{mg} / \mathrm{kg}$ ) adult (10-14 week, 250-300 g) Sprague Dawley rats. Hippocampi were dissected in ice-cold medium containing $10 \mathrm{~mm} \mathrm{MgCl}_{2}$ and no added $\mathrm{CaCl}_{2}$ (see below) and sliced ( $400 \mu \mathrm{m}$ thick) using a McIlwain chopper. $\mathrm{CaCl}_{2}$ was added to the slice incubation buffer to $2 \mathrm{~mm}$, and the temperature of the medium was gradually warmed to $30^{\circ} \mathrm{C}$ over $30 \mathrm{~min}$. Slices were then transferred to standard medium for at least 30-45 $\mathrm{min}$ before transfer to a submersion recording chamber $(\sim 0.8 \mathrm{ml})$ and constantly perfused at $2-3 \mathrm{ml} / \mathrm{min}\left(31^{\circ} \mathrm{C}\right)$. Standard medium for electrophysiological recordings consisted of 124 $\mathrm{mm} \mathrm{NaCl}, 3 \mathrm{~mm} \mathrm{KCl}, 4 \mathrm{~mm} \mathrm{MgCl}_{2}, 4 \mathrm{~mm} \mathrm{CaCl}_{2}, 2$ mM $\mathrm{NaH}_{2} \mathrm{PO}_{4}, 26 \mathrm{~mm} \mathrm{NaHCO}, 10 \mathrm{~mm}$ dextrose, and $10 \mathrm{~mm}$ HEPES ( $\mathrm{pH} 7.35$ ); media were continuously gassed with $95 \% \mathrm{O}_{2}$ and $5 \% \mathrm{CO}_{2}$. Changes in the standard medium are noted in the text and in the figure legends. Taking into account the flow rate and chamber volume, we calculated that switching from standard media to a solution containing $600 \mathrm{~nm}$ kinase inhibitor (concentration used most often), the inhibitor concentration was $\sim 428 \mathrm{~nm}$ in the slice chamber after $1 \mathrm{~min}$ and 596 nM after $2 \mathrm{~min}$.

\section{ELECTROPHYSIOLOGY AND DATA ANALYSIS}

Field-potential recordings from stratum radiatum in area CA1 of hippocampal slices were obtained using 1-3 $\mathrm{M} \Omega$ recording electrodes filled with standard medium. Schaffer collaterals were stimulated at a rate of $0.05-0.1 \mathrm{~Hz}$ with tungsten monopolar (20-50 $\mu \mathrm{m})$-stimulating electrodes (Frederick Haer \& Co., Brunswick, ME). LTP was induced by HFS that consisted of a $100 \cdot \mathrm{Hz}$ train for $1 \mathrm{sec}$ repeated two times at 30 -sec intervals at test stimulation intensity. In experiments with $\mathrm{K}-252 \mathrm{a}$ or DMSO application $45 \mathrm{~min}$ after HFS (Fig. 7A, below), the HFS induction protocol was modified to facilitate the induction of stable LTP for $2 \mathrm{hr}$. Instead of using two trains of $100 \mathrm{~Hz}$ stimulation, four 1-sec trains of $100 \mathrm{~Hz}$ were given at $30-\mathrm{sec}$ intervals at test stimulation intensity. Data were digitized on a Nicolet 410 oscilloscope and analyzed on a computer with custom software that computed excitatory postsynaptic potential
(EPSP) slopes and amplitudes. The initial EPSP slopes (or amplitudes where designated) were normalized to a baseline value obtained by averaging EPSP slopes for $10 \mathrm{~min}$ prior to HFS. Each data point represents the average of 2-4 EPSPs obtained during a $30-\mathrm{sec}$ to 1 -min interval. Data presented in each figure are averaged group data from each experimental condition. Standard error of the mean (S.E.M.) is plotted on data points at 5 -min intervals. Values of potentiation \pm S.E.M., relative to pre-HFS baseline, were computed from average values between 55 and $60 \mathrm{~min}$ after HFS, or as otherwise noted. Independent $t$-tests were conducted on data between control and experimental conditions in different slices. Paired $t$-tests were used for two pathway experiments, utilizing a critical $P$ value of 0.05 .

\section{PREPARATION OF PROTEIN KINASE INHIBITORS/ACTIVATORS}

K-252a and staurosporine were purchased from Kamiya Biomedical Co. (Thousand Oaks, CA. ). PDBu was purchased from LC Services. Compounds were dissolved at $1 \mathrm{mg} / \mathrm{ml}$ in DMSO and stored at $-20^{\circ} \mathrm{C}$. We routinely assay the $\mathrm{IC}_{50}$ values for commercially purchased inhibitors against purified CaMKII as described (Malenka et al. 1989). Inhibitors were diluted to desired concentrations in standard media immediately before application to the slices. DMSO concentrations in most experiments were $0.1 \%$ and only reached $0.3 \%$ in the experiments using $5.6 \mu \mathrm{M} \mathrm{K}-252 \mathrm{a}$. These DMSO concentrations did not affect LTP induction, and $0.3 \%$ DMSO had only a transient effect on synaptic transmission (results not shown).

\section{IN SITU PHOSPHORYLATION OF HIPPOCAMPAL PROTEINS}

Hippocampal slices ( $400 \mu \mathrm{m}$ thick; described above) were incubated at $30^{\circ} \mathrm{C}$ in standard medium for $30 \mathrm{~min}$. Media were continuously gassed with $95 \% \quad \mathrm{O}_{2}$ and $5 \% \quad \mathrm{CO}_{2}$ throughout experiments. Slices were transferred to standard medium without added $\mathrm{NaH}_{2} \mathrm{PO}_{4}$ and incubated for 30 min. The in situ ${ }^{32} \mathrm{P}_{\mathrm{i}}$ labeling of hippocampal proteins was carried out in standard medium with low $\mathrm{NaH}_{2} \mathrm{PO}_{4}$ as described previously (Yip and Kelly

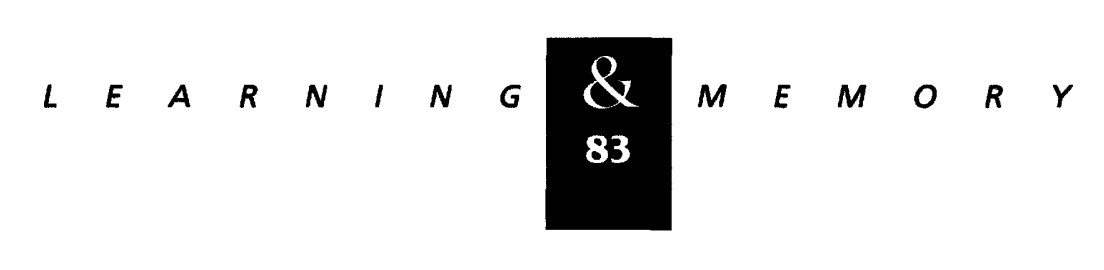


1989). Groups of slices were transferred to individual wells $(2.1 \mathrm{~cm}$ diam.) containing $1 \mathrm{ml}$ of labeling medium $\left(0.5 \mathrm{mCi}\right.$ of $\left.{ }^{32} \mathrm{P}_{\mathrm{i}} / \mathrm{ml}\right)$ of a 12-well tissue culture dish and incubated for $2 \mathrm{hr}$. A manifold was fabricated into the lid of the tissue culture dish to allow for continuous oxygenation of the slices during labeling and drug treatments. Slices were gently shaken throughout the experiments. Slice viability, as measured by recording extracellular EPSPs, persisted for at least $6 \mathrm{hr}$ under these incubation conditions. K252a, DMSO, or PDBu stocks $(1000 \times)$ were diluted into ${ }^{32} \mathbf{P}_{\mathbf{i}}$-labeling solutions. Hippocampal slices were removed from the labeling media at appropriate times and rapidly solubilized in SDS sample buffer at $80^{\circ} \mathrm{C}-$ $90^{\circ} \mathrm{C}$. Protein concentrations were determined using a micro-BCA assay (Hill and Straka 1988).

\section{SDS GEL ELECTROPHORESIS AND PHOSPHOPEPTIDE MAPPING}

Equal amounts of protein ( 30 or $50 \mu \mathrm{g}$ ) from each slice homogenate were analyzed by SDSPAGE (Yip and Kelly 1988). ${ }^{32}$ P-Labeled proteins were localized by autoradiography, and an 80- to 90-kD region of each sample was subjected to a partial digest by Stapbylococcus aureus V8 protease as described (Cleveland et al. 1977; Waxham et al. 1993). Protease-generated phosphopeptides of synapsin I ( 30 and $10 \mathrm{kD}$ ) and MARCKS ( $13 \mathrm{kD}$ ) were separated by SDS-PAGE and visualized by autoradiography. Individual ${ }^{32} \mathbf{P}$-labeled proteins or phosphopeptides were quantitated by Cerenkov counting or with a PhosphorImager SI (Molecular Dynamics). MARCKS and B-50 (GAP43) were extracted from hippocampal slice homogenates ( 200 $\mu g$ ) using the acetic acid extraction procedure described by Robinson et al. (1993) and analyzed by SDS-PAGE. ${ }^{32}$ P-Labeled proteins were visualized by autoradiography and quantitated as described above.

\section{Results}

PROTEIN KINASE INHIBITORS BLOCK LTP INDUCTION WITHOUT AFFECTING SYNAPTIC TRANSMISSION

Experiments utilized a two-pathway paradigm in which independent pathways in stratum radia- tum were alternately stimulated (Dunwiddie and Lynch 1978). Application of K-252a (0.6-1.0 $\mu \mathrm{M})$ from $20 \mathrm{~min}$ before until $20 \mathrm{~min}$ after HFS prevented LTP induction in pathway $\mathrm{S} 1(9 \pm 4 \%$ potentiation, $n=13$; mean \pm S.E.M.; Fig. 1A). At these concentrations, K-252a had no detectable effect on basal synaptic transmission, as demonstrated in pathway S2 $(0 \pm 2 \%$; Fig. 1A). In a subset of experiments $(n=8)$, HFS was given to pathway S2 to test the reversibility of K-252a treatments. Sustained potentiation was obtained in pathway S2 $>30$ min after K-252a washout ( $27 \pm 4 \%$ ), indicating that the ability of K-252a to block LTP induction is reversible. Similar to other studies (Muller et al. 1992), staurosporine (2-4 $\mu \mathrm{M})$ applied 20 min before until $20 \mathrm{~min}$ after HFS reduced the magnitude of LTP (16 $4 \%, n=3$; Fig. 1B) compared with LTP in control slices $(41 \pm 5 \%, n=8$, $P<0.05$ ). Unlike K-252a, the action of staurosporine was not as reversible and LTP could not be induced in control pathways when tetani were delivered within $\mathbf{3 0} \mathrm{min}$ after staurosporine washout (results not shown). Therefore, K-252a was used in many of the experiments that follow.

\section{K-252a DOES NOT AFFECT NMDA RECEPTOR-MEDIATED SYNAPTIC TRANSMISSION}

It has been suggested that one of the roles of protein kinases in LTP induction is to modulate NMDA receptor activity during HFS (Ben-Ari 1992; Muller et al. 1992). To determine whether the ability of K-252a to block LTP was by attenuating NMDA receptor activity, we monitored the effect of K-252a on NMDA receptor EPSPs. NMDA receptor-mediated EPSPs were isolated by the addition of the non-NMDA receptor antagonist 6-cyano-7-nitroquinoxaline-2,3-dione (CNQX; $10 \mu \mathrm{M}$ ) and lowering extracellular $\mathrm{Mg}^{2+}$ to $0.2 \mathrm{~mm}$ (Muller et al. 1990). Because K-252a did not affect synaptic transmission mediated by non-NMDA glutamate receptors (Fig.1), we expected that any attenuation of NMDA receptor-mediated EPSPs would reflect a specific postsynaptic modulation of the receptor and not an affect on presynaptic mechanisms of glutamate release. K-252a $(2 \mu \mathrm{M})$ was applied to slices after stable EPSPs were obtained (Fig. 2). K-252a did not significantly attenuate NMDA receptor-mediated EPSPs. EPSPs recorded in CNQX and low $\mathrm{Mg}^{2+}$ were abolished completely by the NMDA receptor antagonist D,LAPV $(50 \mu \mathrm{M})$. Therefore, concentrations of K-252a

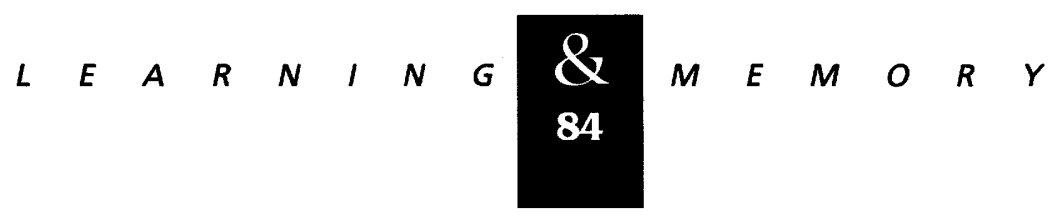



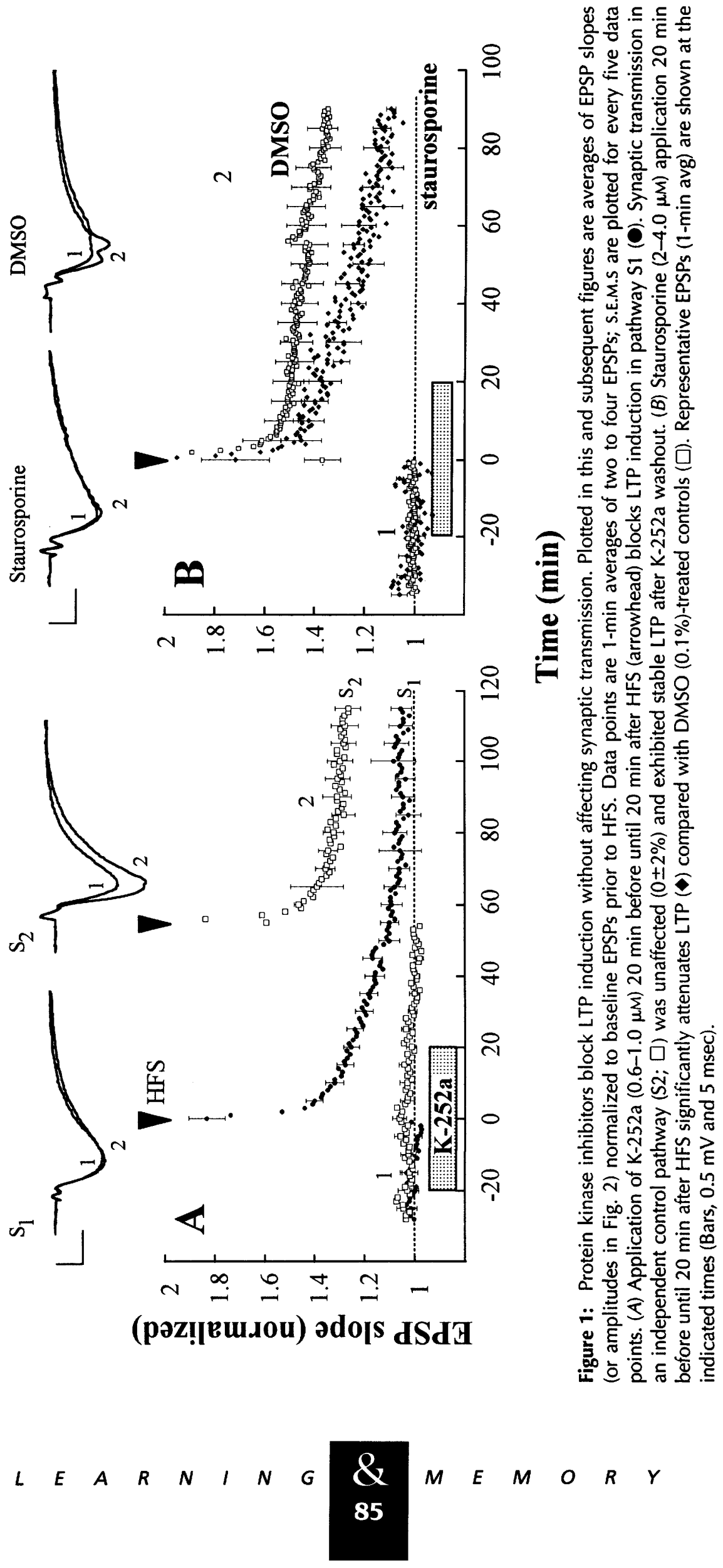
Huber et al.

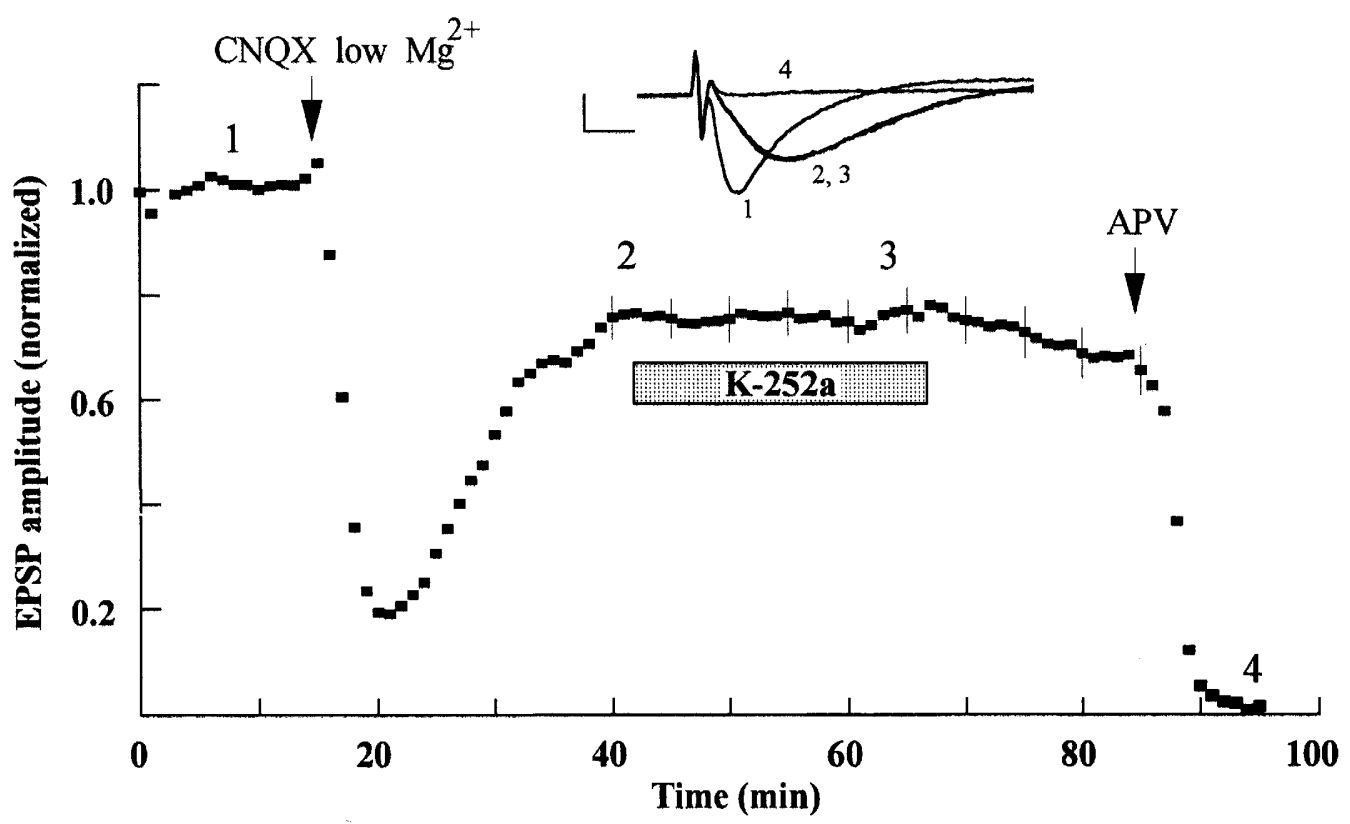

Figure 2: $\mathrm{K}-252 \mathrm{a}$ does not attenuate NMDA receptor-mediated EPSPs. NMDA receptor-mediated EPSPs were isolated in medium containing CNQX $(10 \mu \mathrm{M})$ and reduced $\mathrm{MgCl}_{2}(0.2 \mathrm{mM})$. K-252a (2 $\mu \mathrm{M}$ for $\left.25 \mathrm{~min}\right)$ was applied after NMDA receptor-mediated EPSPs stabilized. EPSPs obtained in CNQX/low $\mathrm{Mg}^{2+}$ were blocked by APV (50 $\left.\mu \mathrm{M}\right)$. Amplitudes of NMDA receptor EPSPs are an average of eight experiments. Amplitude values before K-252a and after APV applications are from a representative experiment demonstrating the time course of $\mathrm{CNQX} / \mathrm{low} \mathrm{Mg}^{2+}$ and APV applications. Representative EPSPs are shown at the times indicated (Bars, $0.5 \mathrm{mV}$ and $5 \mathrm{msec}$ ).

that effectively blocked LTP induction did not attenuate NMDA receptor EPSPs under low-frequency stimulation conditions ( 1 every $15 \mathrm{sec}$ ).

\section{K-252a REDUCES PHORBOL ESTER ENHANCEMENT OF SYNPATIC TRANSMISSION}

To determine more accurately the time course of K-252a's penetration into cells in 400$\mu \mathrm{m}$ slices and its ability to inhibit protein kinase activity in situ, we measured the ability of K-252a to block the effects of PDBu, a membrane-permeable activator of PKC. Several groups have demonstrated that application of PDBu to hippocampal slices induces a robust increase in synaptic strength (Malenka et al. 1986; Muller et al. 1988a). We observed a prolonged enhancement of EPSP slope ( $85 \pm 10 \%, n=23$; Fig. $3 \mathrm{~A})$ measured $55-60$ min after PDBu application ( $1 \mu \mathrm{M}$ for $10 \mathrm{~min}$ ). Preincubation of slices in $0.6 \mu \mathrm{M} \mathrm{K}-252 \mathrm{a}$ for $20 \mathrm{~min}$ significantly reduced PDBu enhancement of synaptic transmission to $18 \pm 12 \%(n=10, P<0.01$; Fig. 3A). In additional experiments, we examined the minimum preapplication period required to block PDBu effects; a 10-min preincubation of 2 $\mu \mathrm{M}$ K-252a was required to significantly reduce PDBu potentiation to $17 \pm 7 \%(n=8, P<0.01$; results not shown). Preincubations of K-252a for 5 min were ineffective, and 7 -min preincubations were variable in their inhibition of PDBu potentiation (results not shown). These results indicate that a 10-min preincubation of K-252a is sufficient to penetrate neurons and reduce the effects of PDBu by $79 \%$.

\section{REVERSIBILITY OF K-252a INHIBITION}

Because the ability of K-252a to block LTP was reversible (Fig. 1), we wanted to examine the kinetics of inhibitor washout using PDBu-induced potentiation. Slices were preincubated for $40 \mathrm{~min}$ in $0.6 \mu \mathrm{M}$ K-252a; its washout was initiated simultaneously with a $10-\mathrm{min}$ application of PDBu (1.0 $\mu M)$. Pretreatment with K-252a had no discernible effect on the initial time course of subsequent PDBu potentiation (shaded area; Fig. 3B) when compared with PDBu potentiation in naive slices. It is interesting to note that preincubation in K-252a appears to have enhanced the magnitude of $\mathrm{PDBu}$ potentiation $(142 \pm 24 \%, n=7$ vs.

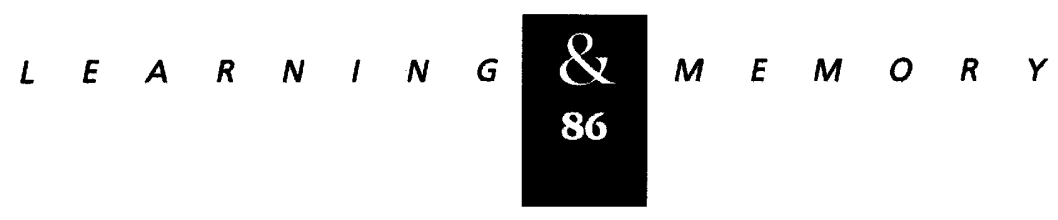




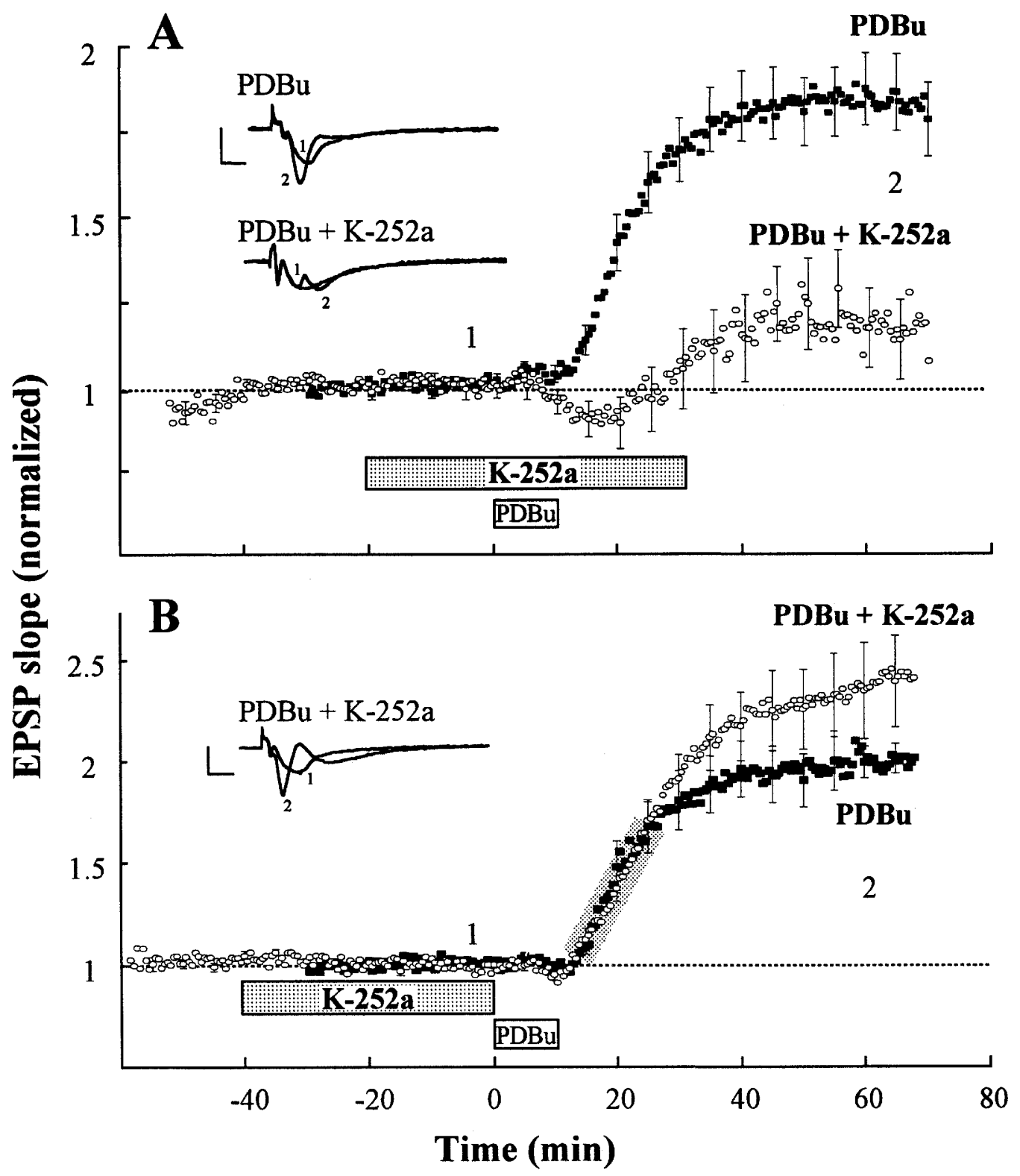

Figure 3: (A) K-252a reduces PDBu-induced synaptic potentiation. PDBu applications to hippocampal slices (1 $\mu \mathrm{M}$ for $10 \mathrm{~min})$ induced a sustained enhancement of synaptic transmission ( $\mathrm{\Pi})$. Application of K-252a $(0.6 \mu \mathrm{M}) 20 \mathrm{~min}$ before until 20 min after PDBu applications significantly attenuated PDBu potentiation (O). (B) The effects of K-252a are reversible. Application of $\mathrm{K}-252 \mathrm{a}(0.6 \mu \mathrm{M})$ to slices for $40 \mathrm{~min}$ prior to PDBu application did not significantly alter the initial time course (shaded area) or degree of PDBu potentiation. K-252a washout and PDBu application were simultaneously initiated. The magnitude of PDBu potentiation is slightly, but not significantly $(P>0.1)$, enhanced in $\mathrm{K}-252 \mathrm{a}$ pretreated slices (O) compared with PDBu alone $(\square)$. Representative EPSPs are shown at the indicated times (Bar, $0.5 \mathrm{mV}$ and $5 \mathrm{msec}$ ).

$100 \pm 6 \%, n=8$ with PDBu alone); however, this enhancement was not significant ( $t$-test, $P>0.1$ ). Because the first effects of PDBu on synaptic transmission are not observed until 10-12 min after the onset of PDBu application (Fig. 3), we estimate that $\mathrm{K}-252 \mathrm{a}$ reaches an ineffective concentration within $\sim 10 \mathrm{~min}$ after washout begins.

\section{K-252a INHIBITS IN SITU PHOSPHORYLATION OF HIPPOCAMPAL PROTEINS}

$\mathrm{K}$-252a was potent in reducing $\mathrm{PDBu}$-induced synaptic enhancement (Fig. 3). To further examine whether $\mathrm{K}-252 \mathrm{a}$ was penetrating neurons and inhibiting protein kinases, we examined the effects

$$
\text { ……" }
$$


of $\mathrm{K}-252 \mathrm{a}$ on the in situ phosphorylation of specific hippocampal proteins. Hippocampal slices were incubated in ${ }^{32} \mathrm{P}_{\mathrm{i}}$ that is incorporated into ATP and used for the phosphorylation of endogenous proteins (Yip and Kelly 1989). The phosphorylation of three neuronal proteins was examined: (1) synapsin I, a synaptic vesicle-associated protein phosphorylated by both cAMP-dependent protein kinase (PKA) and CaMKII (Sudhof et al. 1989); (2) MARCKS, a specific PKC substrate (Wu et al. 1982); and (3) B-50 (GAP43), a presynaptic PKC substrate whose phosphorylation is persistently increased after LTP induction (Gianotti et al. 1992). A partial proteolytic digestion of synapsin I by $S$. aureus V8 protease was used to generate discrete phosphopeptides (30- and 10-kD peptides) that allowed the determination of K-252a inhibition of CaMKII and PKA activities (Huttner and Greengard 1979; Waxham et al. 1993). Two K252a incubation protocols were utilized to determine the effects of K252a on in situ protein phosphorylation. Slices were either incubated in a low-concentration K-252a ( $2 \mu \mathrm{M}$ for 40 min) or treated with $2 \mu \mathrm{M}$ K-252a for $30 \mathrm{~min}$ and $5 \mu \mathrm{M} \mathrm{K252a}$ for an additional $10 \mathrm{~min}$. These conditions were analyzed because different effects on LTP induction were observed, depending on which inhibitor incubation protocol was used (see Figs. 5 and 6, below). Incubation of slices in K-252a ( $2 \mu \mathrm{M}$ for $40 \mathrm{~min}$ ) reduced basal phosphorylation of the $30-\mathrm{kD}(29 \pm 4 \%, P<0.001, n=7$; CaMKII site) and 10-kD (64 $\pm 4 \%, P<0.001, n=6$; PKA site) phosphopeptides of synapsin I and B-50 (63 $\pm 6 \%, P<0.001, n=7$ ) compared with their phosphorylation in slices incubated in DMSO
(0.1\%; Fig. 4). Phosphorylation values for the DMSO controls $(n=9)$ were set at $100 \%$, and inhibitor values (mean \pm S.E.M.) were normalized to them. Increasing K-252a to $5 \mu \mathrm{M}$ for the last 10 min of the incubation period altered the phosphorylation of $30-\mathrm{kD}(16 \pm 5 \%, P<0.001, n=6)$ and $10-\mathrm{kD}(60 \pm 4 \%, P<0.001, n=7)$ phosphopeptides of synapsin $I$ as well as B-50 (65 $\pm 7 \%, P<0.01$, $n=5$ ). Interestingly, increasing K-252a to $5 \mu \mathrm{M}$ did not significantly increase the inhibition of ${ }^{32} \mathrm{P}$ incorporation observed at $2 \mu \mathrm{M} \mathrm{K}-252 \mathrm{a}$. The in situ phosphorylation of MARCKS was not significantly reduced by either inhibitor incubation protocols $[95 \pm 10 \%$ at $2 \mu \mathrm{M}(n=7)$ and $86 \pm 13 \%$ at $2-5 \mu \mathrm{M}$ $(n=4)]$.

Because K-252a significantly reduced PDBuinduced synaptic enhancements (Fig. 3), we tested the ability of K-252a to block PDBu's stimulation of in situ protein phosphorylation. A 10 min application of PDBu (10 $\mu \mathrm{M})$ stimulated the phosphorylation of the $30-\mathrm{kD}$ site in synapsin I $(136 \pm 10 \%, P<0.01, n=6)$, MARCKS $(232 \pm 5 \%$, $P<0.001, n=4)$, and B-50 (134 $\pm 7 \%, P<0.01$, $n=5$; Fig. 4). PDBu stimulation of synapsin I phosphorylation has been reported elsewhere (Browning and Dudek 1992). Preincubation of slices in K-252a ( $2 \mu \mathrm{M}$ for $40 \mathrm{~min}$ ) reduced PDBu-stimulated phosphorylation of all proteins examined, including synapsin I $[20 \pm 6 \%, P<0.001(n=5)$ for $30-\mathrm{kD}$ and $66 \pm 13 \%(n=4)$ for $10-\mathrm{kD}$ phosphopeptides], MARCKS $(90 \pm 2 \%, n=5)$, and B-50 ( $40 \pm 3 \%, P<0.001, n=5$; Fig. 4). Likewise, the 2-5 $\mu$ M K-252a protocol significantly inhibited $\mathrm{PDBu}$-stimulated ${ }^{32} \mathrm{P}$ incorporation into synapsin I $[25 \pm 4 \%, P<0.001 \quad(n=5)$, for $30-\mathrm{kD}$ and
Figure 4: K-252a inhibits the in situ phosphorylation of specific hippocampal proteins. Slices were incubated in $\mathrm{K}-252 \mathrm{a}(2 \mu \mathrm{M}$ or $2-5 \mu \mathrm{M})$ using the protocols described in Results. In certain experiments, in situ phosphorylation was stimulated by a $10-$ min treatment with PDBu $(10 \mu \mathrm{M})$ alone or at the end of K-252a treatments. The in situ phosphorylation of the following neuronal proteins was determined in the presence of $\mathrm{K}-252 \mathrm{a}$ plus or minus PDBu, or in PDBu alone: MARCKS; B-50; the 10-kD phosphopeptide of synapsin I; and the 30-kD phosphopeptide of synapsin I ( $n=9$ for DMSO controls). Significant differences from baseline $(100 \%)$ were determined using separate $t$-tests (two-tailed).

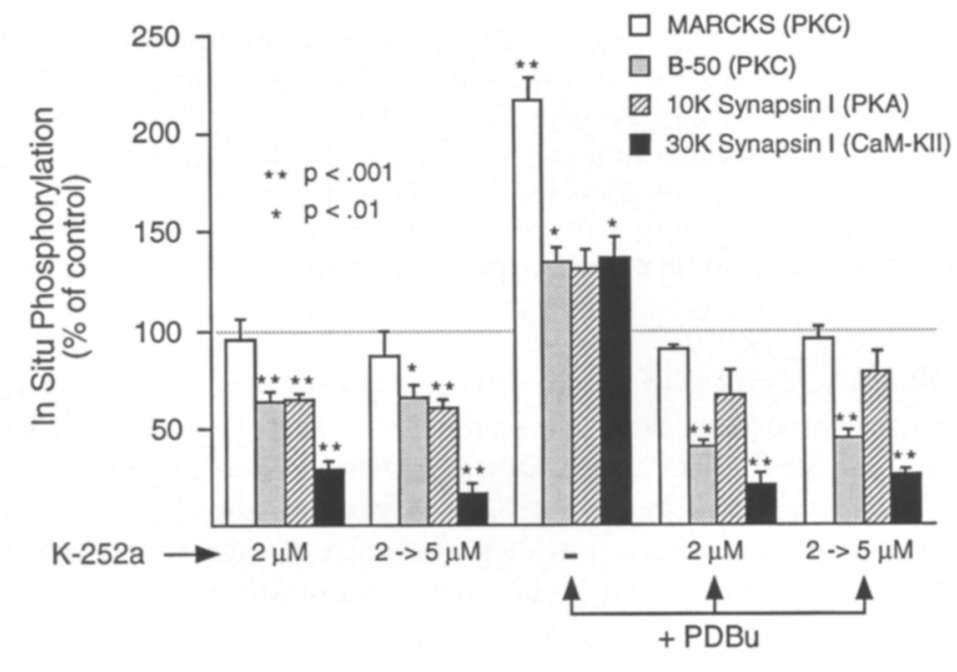

$\begin{array}{llllll}M & E & M & O & R & Y\end{array}$ 
$78 \pm 11 \%(n=6)$ for $10-\mathrm{kD}$ phosphopeptides), MARCKS $(95 \pm 6 \%, n=5)$, and B-50 $(44 \pm 4 \%$, $P<0.001, n=5$; Fig. 4); however, these values were not significantly less than those obtained with $2 \mu \mathrm{M}$ K-252a. These results indicate that $\mathrm{K}-252 \mathrm{a}$ is an effective inhibitor of in situ phosphorylation of hippocampal proteins at the same concentrations used to block LTP.

\section{K-252a APPLICATION BEFORE AND DURING HFS DOES NOT BLOCK LTP}

The reversibility of K-252a (Figs. 1 and 3B) makes it suitable to study the time course of protein kinase activity required for LTP induction. Application of K-252a (0.6-2 $\mu \mathrm{M}) 40 \mathrm{~min}$ before, and its washout immediately after HFS did not block LTP induction ( $41 \pm 6 \%, n=8$; Fig. 5). The magnitude of potentiation observed in these experiments was significantly greater than potentiation in slices with pre- plus post-HFS applications of

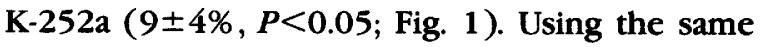
experimental design, we examined the effects of delaying the washout of K-252a until $5 \mathrm{~min}$ after HFS. This treatment did not significantly attenuate

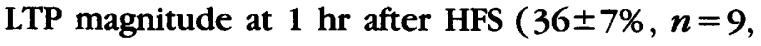
$P>0.5$; Fig. 5) compared with LTP in control slices $(41 \pm 8 \%, n=7)$. These results suggest that the ability of kinase inhibitors to block LTP is not a result of their action during HFS and that kinase activity after HFS is required for LTP induction and expression.

\section{HIGH CONCENTRATIONS OF K-252a DURING HFS BLOCK LTP INDUCTION}

An alternative explanation of the results just described is that the concentrations of $\mathrm{K}-252 \mathrm{a}$ $(0.6-2 \mu M)$ used in these experiments simply failed to block LTP induction because increases in second messengers (i.e., $\mathrm{Ca}^{2+}$; Müller and Connor $1991)$ triggered by HFS may activate protein ki-

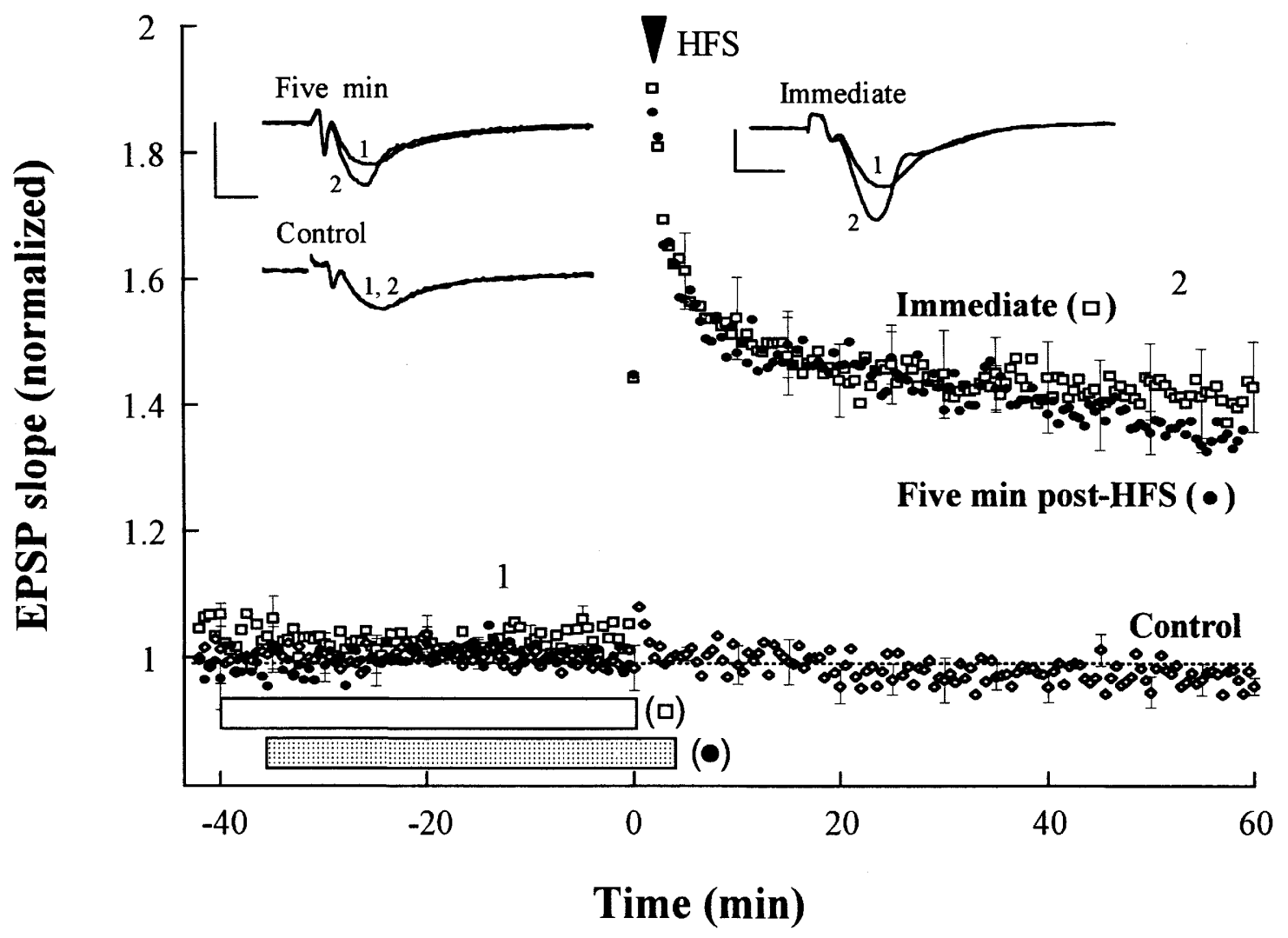

Figure 5: $\quad \mathrm{K}-252 \mathrm{a}$ applications before and during HFS do not block LTP. K-252a applications $(0.6-2.0 \mu \mathrm{M}) 40 \mathrm{~min}$ before and washout immediately ( $\square$ ) or $5 \mathrm{~min}(\bigcirc)$ after HFS did not attenuate the magnitude of LTP. K-252a did not significantly affect synaptic transmission in control pathways $(3 \pm 3 \% ; \diamond)$. Representative EPSPs are shown at the indicated times (Bars, $0.5 \mathrm{mV}$ and $5 \mathrm{msec}$ ).

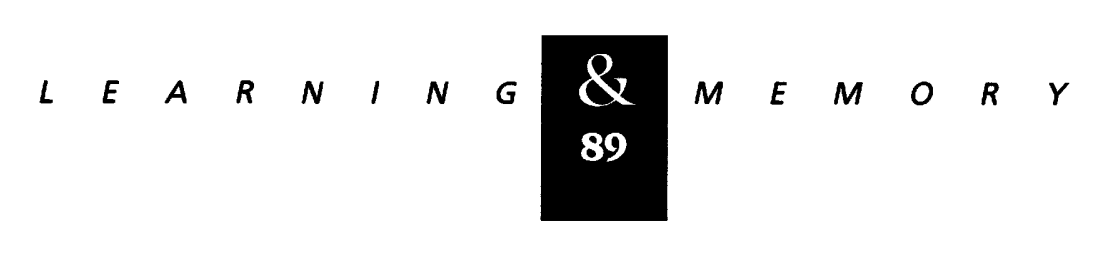


nases to a high level that are not sufficiently inhibited. However, 40-min applications of high concentrations of $\mathrm{K} \cdot 252 \mathrm{a}(5-20 \mu \mathrm{M})$ routinely and irreversibly depressed synaptic transmission ( $\sim 15 \%$; results not shown). Shorter applications (5-10 min) of $5 \mu \mathrm{M} \mathrm{K-252a}$ had no consistent effect on synaptic transmission. Therefore, we modified the 40-min treatment in which a low concentration of K-252a $(0.6 \mu \mathrm{M})$ was applied before and during HFS and increased the concentration of $\mathrm{K}-252 \mathrm{a}$ to $5.6 \mu \mathrm{M}$ during the $10-\mathrm{min}$ period just prior to and during HFS. This higher concentration of $\mathrm{K}-252 \mathrm{a}$ during HFS significantly reduced the magnitude of LTP ( $11 \pm 3 \%, n=6$; Fig. 6A) when compared with DMSO controls $(41 \pm 7 \%, n=8$, $P<0.05$ ). The attenuation of LTP magnitude by 5.6 $\mu \mathrm{M}$ K-252a cannot be attributed to its small effect on synaptic transmission in control pathways ( $-5 \pm 2 \%, n=6$; Fig. 6A).

The higher concentration of K-252a may block LTP induction because it is more effective in blocking kinase activation during HFS or because it diffuses out of slices slower than the $0.6 \mu \mathrm{M}$ K-252a and blocks LTP induction by inhibiting kinases after HFS. To examine the washout properties of the higher concentration of $\mathrm{K}-252 \mathrm{a}$, we tested the reversibility of $5.6 \mu \mathrm{M} \mathrm{K}-252 \mathrm{a}$ by its inhibition of PDBu potentiation. The identical K-252a washout protocol used in LTP experiments (see Fig. 6A) was applied immediately before PDBu ( $1 \mu \mathrm{M} ; 10 \mathrm{~min}$ ). This $\mathrm{K}-252 \mathrm{a}$ protocol significantly attenuated PDBu-induced synaptic enhancement ( $30 \pm 23 \%, n=7, P<0.05$; Fig. 6B) when compared with PDBu controls (85 $\pm 10 \%$, $n=23$; Fig. $6 \mathrm{~B}$ ). These results suggest that $5.6 \mu \mathrm{M}$ K-252a may wash out of slices more slowly than lower concentrations (0.6-2 $\mu \mathrm{M})$ and blocks LTP by primarily inhibiting kinase activity after HFS.

\section{PROTEIN KINASE ACTIVITY AFTER HFS IS REQUIRED FOR STABLE LTP}

Because the previous results (Figs. 1 and 4A) suggested that protein kinase inhibition is required before, during, and after HFS to block LTP induction, we tested whether inhibition of protein kinase activity after HFS alone is sufficient to disrupt LTP induction processes. Application of K-252a $(0.6-2 \mu \mathrm{M})$ for $40 \mathrm{~min}$ beginning immediately after HFS resulted in decremental potentiation $(17 \pm 5 \%, n=28$; Fig. $7 \mathrm{~A})$ that was significantly less $(P<0.001)$ than control slices from the same hippocampus receiving DMSO (0.1\%) alone ( $44 \pm 8 \%, n=11$ ). Some potentiation was evident $\mathbf{l ~ h r}$ after HFS; however, in a subset of experiments $(n=4)$, potentiation was monitored and returned to baseline $120 \mathrm{~min}$ after HFS (6士4\%; data not shown). In other experiments, post-HFS applications of high concentration of K-252a (5-10 $\mu \mathrm{M})$ were tested for a more complete block of LTP within $1 \mathrm{hr}$ after HFS and, as mentioned above, these K-252a concentrations depressed basal or nonpotentiated synaptic transmission (results not shown). Staurosporine (2-4 $\mu \mathrm{M})$ applications initiated immediately after HFS reduced the magnitude of LTP to $18 \pm 6 \%(n=5, P<0.05$; Fig. 7A) when compared with LTP in control slices ( $41 \pm 5 \%, n=8)$.

Delaying K-252a (0.6 $\mu \mathrm{M})$ applications until 5 min after HFS significantly attenuated LTP when measured at 60 and $90 \mathrm{~min}(19 \pm 6 \%$ and $12 \pm 6 \%$, respectively; $P<0.05, n=9$; Fig. $7 \mathrm{~B}$ ) when compared with LTP in DMSO-treated controls

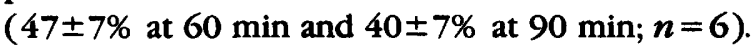
These results indicate that protein kinase activity after HFS is required to induce LTP.

\section{K-252a HAS LITTLE EFFECT ON LTP EXPRESSION}

Because the above experiments indicated that protein kinase activity is required after HFS, we examined the length of time that protein kinases must be active after HFS to test for a role of protein kinases during LTP expression. K-252a (0.6 $\mu \mathrm{M})$ was applied for $40 \mathrm{~min}$, beginning $45 \mathrm{~min}$ until 85 min after HFS, and produced a slight attenuation in the magnitude of LTP expression (26 $4 \%$ at 120 min after HFS; $n=7$ ) compared with LTP in control slices treated with DMSO (0.1\% ) 45-85 min after HFS (39 $\pm 7 \%, n=8$; Fig. 8A). This attenuation, however, was not significant (independent $t$-test, $P>0.2$ ). Because a slight attenuation of LTP magnitude was observed with a 45 -min post-HFS application of K-252a, inhibition of protein kinases earlier ( $30 \mathrm{~min}$ ) after HFS could produce a greater reduction in LTP magnitude. K-252a $(0.6 \mu \mathrm{M})$ application 30-70 min after HFS did not significantly attenuate LTP magnitude observed $90 \mathrm{~min}$ after HFS (22 $\pm 7 \%, n=6$; Fig. 8B) compared with DMSO-treated control slices $(32 \pm 7 \%, n=8$, $P>0.2)$. These results suggest that persistent protein kinase activity 30-85 min after HFS contributes little to LTP expression, and, therefore, protein kinase activity-independent mechanisms may be mostly responsible for maintaining LTP.

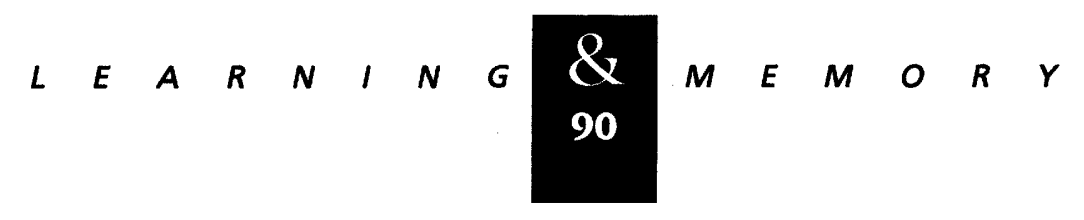



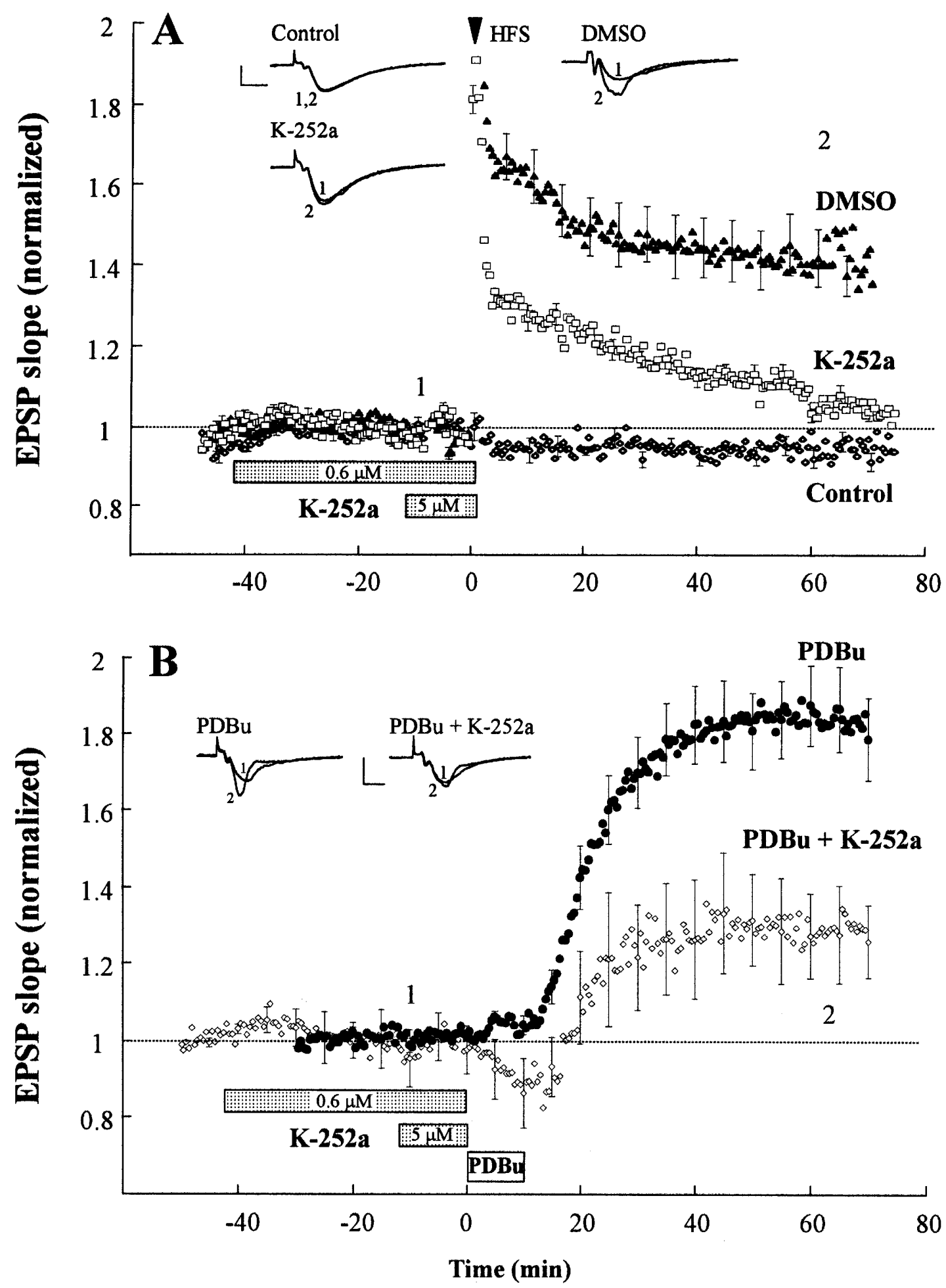

Figure 6: LTP is blocked by high concentrations of K-252a applied shortly before and during HFS. (A) K-252a (0.6 $\mu \mathrm{M})$ was applied to slices beginning $40 \mathrm{~min}$ before HFS and increased to $5.6 \mu \mathrm{M} 10 \mathrm{~min}$ prior to and during HFS. This protocol blocked LTP induction ( $\square$ ) without significantly attenuating control pathways $(-5 \pm 2 \% ; \diamond)$. DMSO $(0.1 \%$ and $0.3 \%)$ treated control slices exhibited robust LTP $(\mathbf{\Delta})$. (B) PDBu-induced potentiation is inhibited by prior application of high $\mathrm{K}-252 \mathrm{a}$ concentrations. Slices were pretreated with the same K-252a protocol $(0.6-5.6 \mu \mathrm{M})$ described in $A$ immediately before PDBu application (1 $\mu \mathrm{M}$ for $10 \mathrm{~min}$ ). This pretreatment significantly attenuated PDBu potentiation $(\diamond)$ compared with PDBu alone (). Representative EPSPs are shown at the indicated times (Bars, $0.5 \mathrm{mV}$ and $5 \mathrm{msec}$ ).

$$
\text { ……………… }
$$


Huber et al.

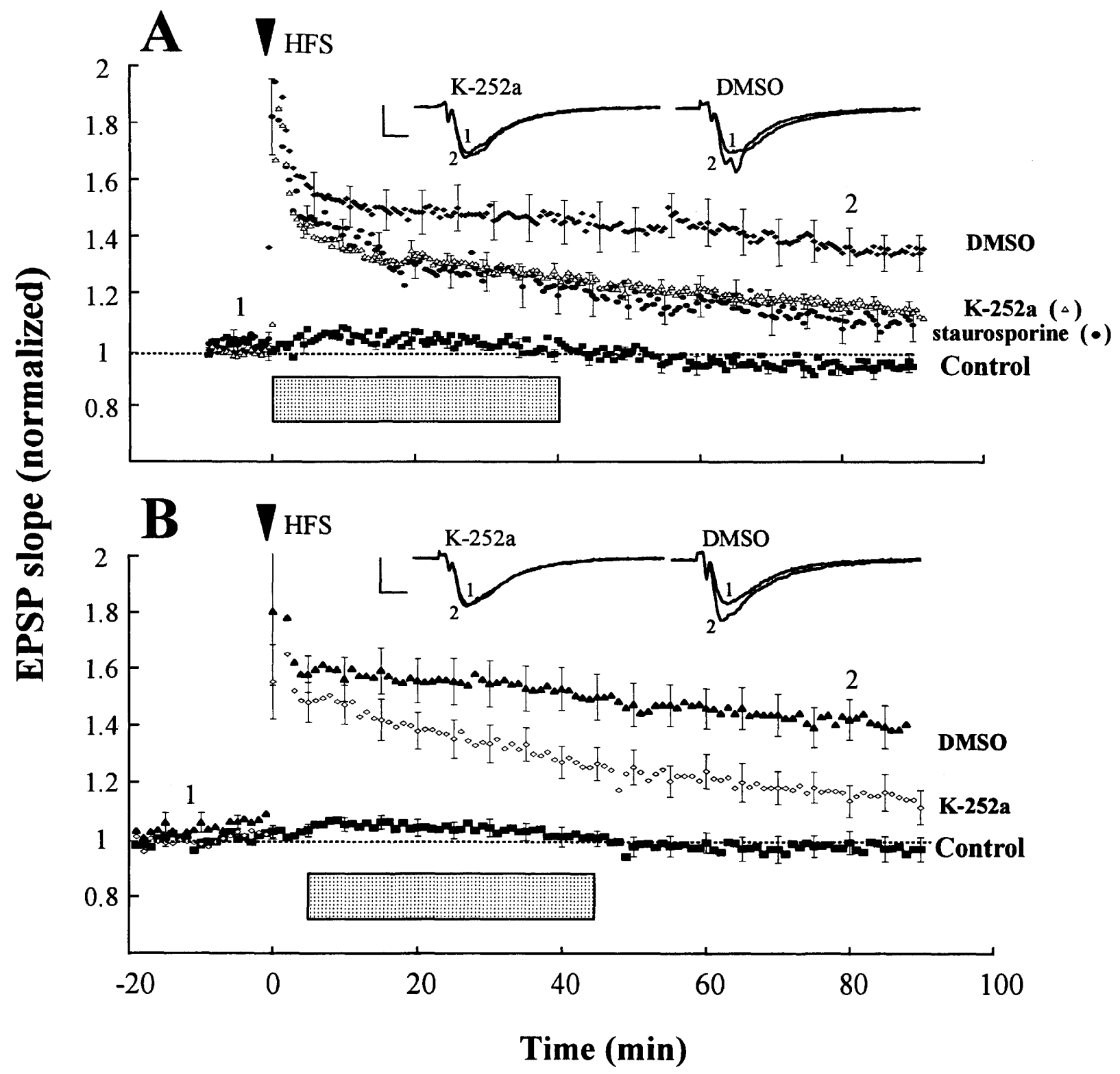

Figure 7: Protein kinase activity after HFS is required for stable LTP expression. (A) K-252a $(0.6-2.0 \mu \mathrm{M} ; \Delta)$ or staurosporine (2-4 $\mu \mathrm{M} ; O)$ application immediately after HFS significantly attenuated the magnitude of LTP compared with DMSO-treated control slices $(\bullet)$. Neither inhibitor significantly affected synaptic transmission in control pathways $(-4 \pm 3 \%$; $)$. (B) Delaying K-252a $(0.6 \mu \mathrm{M} ; \diamond)$ applications until $5 \mathrm{~min}$ after HFS significantly attenuated the magnitude of LTP compared with DMSO controls $(\boldsymbol{\Delta})$. K-252a did not significantly affect synaptic transmission in control pathways $(-2 \pm 4 \% ; \square)$. Representative EPSPs are shown at the indicated times (Bars, $0.5 \mathrm{mV}$ and $5 \mathrm{msec}$ ).

\section{Discussion}

The focus of these studies was to obtain new information about the period of protein kinase activity required for LTP induction and expression. We systematically examined the actions of membrane-permeable inhibitors of protein kinases on (1) synaptic transmission, (2) PDBu-induced po- tentiation, (3) in situ protein phosphorylation, and (4) LTP induction and expression. K-252a (0.6-2 $\mu \mathrm{M})$ or staurosporine (2-4 $\mu \mathrm{M})$ blocked LTP induction when present $20 \mathrm{~min}$ before until $20 \mathrm{~min}$ after HFS (Fig. 1). In contrast, K-252a (0.6-2 $\mu \mathrm{M})$ did not block LTP induction when applied before and during, and washed out immediately after HFS

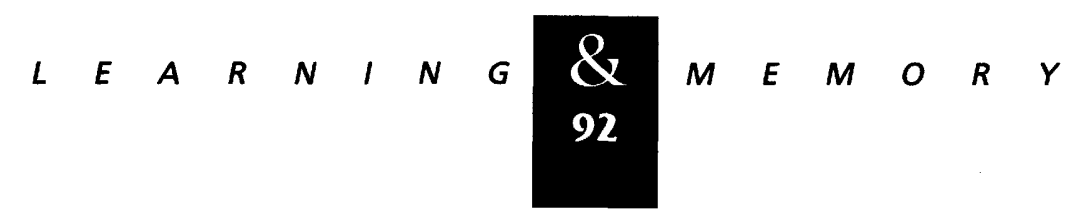



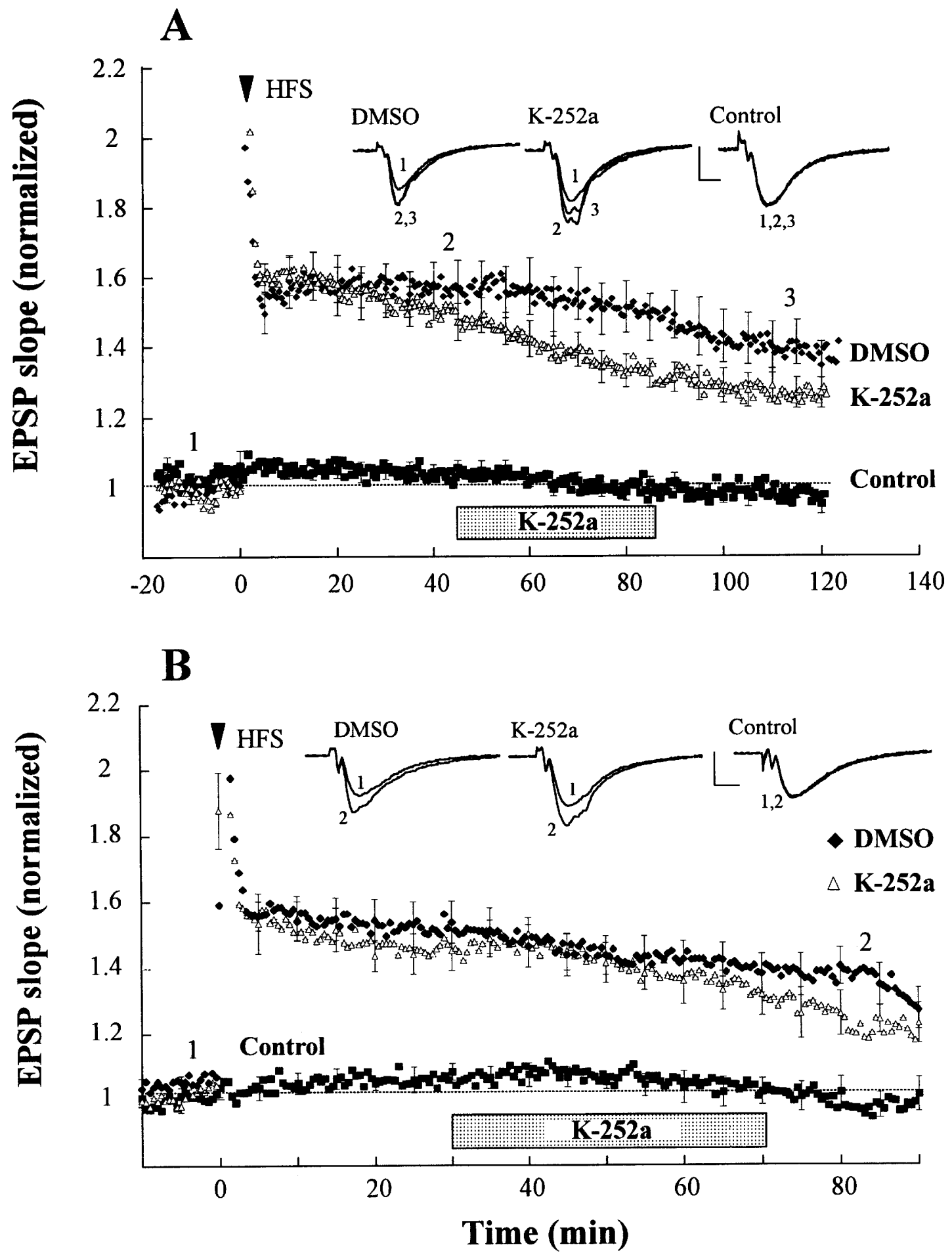

Figure 8: $\quad \mathrm{K}-252 \mathrm{a}$ has little effect on LTP expression. (A) $\mathrm{K}-252 \mathrm{a}$ application $(0.6 \mu \mathrm{M} ; \triangle)$ beginning 45 min until 85 min after HFS did not significantly attenuate LTP measured at 120 min after HFS when compared with DMSO controls (0.1\%; $\bullet)$. Control synaptic transmission was not significantly affected $(-2 \pm 2 \%$; $\square)$. (B) K-252a application $(0.6 \mu \mathrm{M} ; \Delta)$ beginning $30 \mathrm{~min}$ until $70 \mathrm{~min}$ after HFS did not significantly attenuate LTP magnitude observed 90 min after HFS compared with DMSO control slices $(0.1 \% ; \bullet)$. Control synaptic transmission was not significantly affected $(-2 \pm 4 \%$; च). Representative EPSPs are shown at the indicated times (Bars, $0.5 \mathrm{mV}$ and $5 \mathrm{msec}$ ).

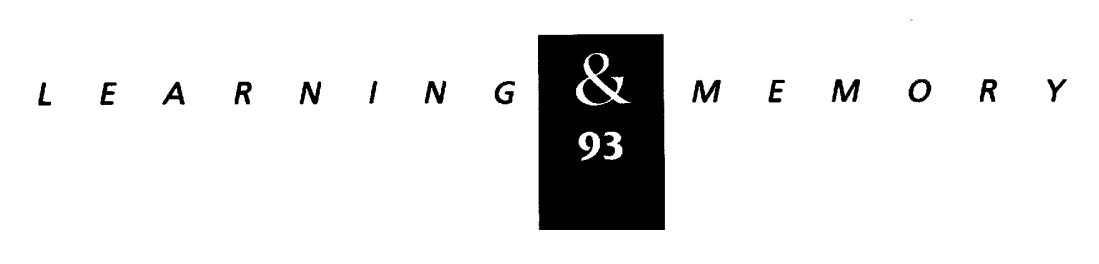


(Fig. 5). The application of inhibitors immediately or 5 min after HFS reduced the magnitude of LTP significantly (Fig. 7), whereas K-252a applications initiated 30-45 min after HFS did not attenuate LTP expression significantly (Fig. 8). Our results suggest that the critical period of protein kinase activity required for LTP induction occurs after HFS.

$\mathrm{K}-252 \mathrm{a}$ has been shown to inhibit nerve growth factor (NGF)-stimulated protein phosphorylation in PC12 cells (Hashimoto 1988), but its effects on in situ phosphorylation in hippocampal slices had not been determined previously. We observed potent inhibitory effects of K-252a on the in situ phosphorylation of hippocampal proteins, indicating that it inhibits endogenous protein kinases and the in situ phosphorylation of hippocampal proteins at the same concentrations at which it blocks LTP. However, K-252a was not equipotent in inhibiting the phosphorylation of all proteins [two-way ANOVA, $\mathbf{F}(3,41)=40.82$, $P<0.001]$. K-252a was significantly more effective in inhibiting the phosphorylation of the $30-\mathrm{kD}$ phosphopeptide of synapsin I (Tukey test, $P<0.01$ ) that is phosphorylated by CaMKII, compared with the PKA site (10 kD) of synapsin I, or the phosphorylation of the PKC substrate B-50 (Fig. 4). In the presence of $\mathrm{K}-252 \mathrm{a}$ alone, the in situ phosphorylation of MARCKS, B-50/10K synapsin I, and $30 \mathrm{~K}$ synapsin I was each significantly different from the other (Tukey test, $P<0.01$ ). This differential inhibition may be related to the relative potencies of $\mathrm{K}-252 \mathrm{a}$ against these kinases as measured by their in vitro $\mathrm{IC}_{50} \mathrm{~s}$. $\mathrm{K}$-252a is most potent against CaMKII $\left(\mathrm{IC}_{50}=3 \mathrm{nM}\right)$ and less effective against PKA or PKC $\left(\mathrm{IC}_{50} \mathrm{~s}=16\right.$ and $25 \mathrm{nM}$, respectively; Kase et al. 1986; Hashimoto et al. 1991 ). However, K-252a also differentially inhibited the phosphorylation of the two PKC substrates examined, B-50 and MARCKS (Fig. 4). Although $\mathrm{K}-252 \mathrm{a}$ reduced ${ }^{32} \mathrm{P}$ labeling of $\mathrm{B}-50$ under both basal and PDBu stimulation conditions, K-252a inhibited only the PDBu stimulation of MARCKS phosphorylation. This result suggests that the basal rate of phosphate turnover for MARCKS may be lower than that of B-50, so that the most robust effects of $\mathrm{K}-252 \mathrm{a}$ are observed when protein kinase activity is stimulated, as in the presence of PDBu. Interestingly, we observed a potent and significant inhibition of synapsin I phosphorylation $(P<0.001)$ at a K-252a concentration $(2 \mu \mathrm{M})$ that did not alter basal synaptic transmission. Previous studies have indicated that the phosphorylation state of synapsin I may mod- ulate synaptic transmission machinery (Llinas et al. 1985; Lin et al. 1990). In addition, in a recent study it was observed that the effects of peptide protein kinase inhibitors on synaptic transmission correlated with their ability to inhibit the in situ phosphorylation of synapsin I (Waxham et al. 1993). Our results, however, indicate that the phosphorylation of synapsin I may not be strongly correlated with the strength of basal synaptic transmission. In this regard, transgenic mice that do not express synapsin I display normal hippocampal synaptic transmission under low-frequency stimulation conditions and display an increased ratio of paired-pulse facilitation compared with wildtype mice (Rosahl et al. 1993). The latter results suggest that there may be compensatory mechanisms that maintain synaptic transmission in the absence of synapsin I (Rosahl et al. 1993). Thus, the phosphorylation of synapsin I may not be crucial for low-frequency synaptic transmission but may be more important for regulating neurotransmitter release under high-frequency stimulation conditions.

The critical period of protein kinase activity required for LTP induction can only be estimated using membrane-permeable inhibitors. In addition, analysis of PDBu-induced synaptic potentiation provided us with an approximation of the kinetics of K-252a applications (Fig. 3) and indicated that K-252a $(0.6-2 \mu \mathrm{M})$ reached effective concentrations in slices within $10 \mathrm{~min}$ and washed out within $10 \mathrm{~min}$. Because there was a significant difference in LTP magnitude when K-252a was applied before HFS and washed out $20 \mathrm{~min}$ (Fig. 1) versus 5 min after HFS (Fig. 5), we propose that the critical period of protein kinase activity required for LTP induction occurs 5-20 min after HFS. This hypothesis is supported by results from inhibitor applications immediately or $5 \mathrm{~min}$ after HFS that significantly attenuated the magnitude of LTP (Fig. 7). Protein kinase activity during later stages of LTP (30-85 min after HFS) contributed less to LTP expression, because there were insignificant effects of K-252a applications from 30-85 min after HFS (Fig. 8). The requirement for a prolonged window of protein kinase activity suggests that mechanisms underlying LTP induction are not limited to the period during and immediately following HFS. Protein kinases may be activated during HFS, but their persistent activity is required for $\sim 20$ min after HFS. This critical period may be an extended induction phase or an intermediate "consolidation" stage of LTP that is the conversion

$$
\text { ….... 圆 }
$$


of short-term potentiation (STP; Malenka 1989) into more stable LTP maintenance.

The critical period of protein kinase activity observed herein differs from previous reports showing significant attenuation of LTP expression by bath-applied ( $\mathrm{H} 7$; Malinow et al. 1988) or postsynaptically injected (PKC ${ }_{19-31}$, polymixin B; Wang and Feng 1992) protein kinase inhibitors 1 hr after HFS. As mentioned in the introduction, H-7 does not specifically attenuate potentiated pathways and affects basal synaptic transmission (Leahy and Vallano 1991; Muller et al. 1992; Waxham et al. 1993). Results utilizing postsynaptic injection of protein kinase inhibitors (Wang and Feng 1992) appear somewhat controversial because other groups have been unable to impact on LTP expression with postsynaptic injection of PKC and CaMKII inhibitors (Malinow et al. 1989; Huang et al. 1992). Our inability to significantly attenuate LTP expression with $\mathrm{K}-252 \mathrm{a}$ applications beginning 30-45 min after HFS could be attributable to a differential sensitivity or accessibility of protein kinases to K-252a during early (1-20 min) versus late (30-60 min) phases of LTP. K-252a is a competive antagonist of ATP and will inhibit both $\mathrm{Ca}^{2+}$-dependent and -independent PKC and CaMKII activities (Kase et al. 1986). Moreover, our results indicate that the lowest concentration of K-252a $(0.6 \mu \mathrm{M})$ used to block LTP induction inhibits protein kinase activity in situ because this concentration significantly reduces $\mathrm{PDBu}$-induced synaptic potentiation (Fig. 3A). In this regard, postsynaptic injections of multiple or high concentrations of PKC inhibitors (Wang and Feng 1992) may be required to impact LTP expression.

Our observations of a critical period of protein kinase activity are consistent with a recent report that inhibition of enzymatic processes by transient $(4-5 \mathrm{~min})$, rapid cooling $\left(33^{\circ}-24^{\circ} \mathrm{C}\right)$ of hippocampal slices within $20 \mathrm{~min}$ after HFS abolished LTP; however, delaying the cooling period until 25 min after HFS had no effect on potentiation (Bittar and Muller 1993). Another study using guinea pig hippocampal slices demonstrated that LTP can be reversed or depotentiated with $5 \mathrm{~Hz}$ stimulation only within the first $20 \mathrm{~min}$ after LTP induction (O'Dell and Kandel 1994). Attempts to depotentiate $55 \mathrm{~min}$ after HFS were less successful. In addition, depotentiation was dependent on NMDA receptor and protein phosphatase activities. The time course of this protein phosphatasedependent reversal of LTP is consistent with the notion of a critical period of protein kinase activity that occurs during LTP induction and can be reversed by activating phosphatases. After this critical period, synaptic strength is more resistant to manipulations of protein phosphorylation/dephosphorylation. Together, these observations suggest that during the early phase of LTP ( $\leqslant 20$ min after HFS), protein kinases activate mechanisms that result in permanent synaptic changes (e.g., new protein synthesis or morphological changes) responsible for LTP expression.

$\mathrm{Ca}^{2+}$ increases in dendritic spines have been observed for minutes after HFS (Müller and Connor 1991); however, residual $\mathrm{Ca}^{2+}$ is only required for seconds after HFS to activate LTP induction machinery (Malenka et al. 1992). These observations suggest that if a critical period of protein kinase activity is required after HFS, then kinase activity during this period of LTP must be either $\mathrm{Ca}^{2+}$ independent or require the prolonged presence of $\mathrm{Ca}^{2+}$ and/or cofactors (i.e., $\mathrm{Ca}^{2+} /$ calmodulin and DAG). The results herein support studies showing that $\mathrm{Ca}^{2+}$-independent PKC (Klann et al. 1993; Sacktor et al. 1993) and CaMKII activities (Fukanaga et al. 1993) remain elevated for at least $1 \mathrm{hr}$ after LTP induction, but we suggest that kinase activity during an earlier consolidation phase (5-20 min post-HFS) is essential for stable LTP expression.

Although our results (Figs. 4 and 6) indicated that protein kinase activity during HFS is not critical for LTP induction, we tested this hypothesis by using high concentrations of $\mathrm{K}-252 \mathrm{a}(5.6 \mu \mathrm{M}$; Fig. 6) during HFS. We observed that $5.6 \mu \mathrm{M}$ $\mathrm{K}-252 \mathrm{a}$ was able to block LTP when applied 10 min before and during, and washed out immediately after HFS (Fig. 6A). These results suggest two possibilities: (1) At lower K-252a concentrations (i.e., 0.6 and $2 \mu \mathrm{M}$; Fig. 5), LTP is not blocked because protein kinase activity is not sufficiently inhibited during HFS, or (2) at high concentrations (i.e., $5.6 \mu \mathrm{M}$ ), K-252a washes out of slices slowly and blocks LTP induction simply by inhibiting protein kinases after HFS. Our experiments cannot distinguish unambiguously between these two possibilities. However, because the degree of in situ phosphorylation was inhibited approximately the same by $2 \mu \mathrm{M}$ versus $2-5 \mu \mathrm{M} \mathrm{K}-252 \mathrm{a}$ incubation protocols (Fig. 4), we suggest that the block of LTP by $5.6 \mu \mathrm{M} \mathrm{K}-252 \mathrm{a}$ may not be simply the result of a greater inhibition of kinases ( 1 above). Support for possibility (2) (above) is provided by our observation that $5.6 \mu \mathrm{M} \mathrm{K}-252 \mathrm{a}$ washed out of slices much slower (Fig. 6B) than

$$
\text { ……‥ }
$$


$0.6 \mu \mathrm{M}$ (Fig. 3B) in experiments using PDBu potentiation as a measure of K-252a effectiveness. On the other hand, HFS may trigger a burst of kinase activity required for LTP induction that is not sufficiently inhibited by low K-252a concentrations (i.e., $2 \mu \mathrm{M}$ ). However, this burst of kinase activity during HFS alone is not sufficient to produce stable LTP because we were able to attenuate LTP with inhibitor applications 5 min after HFS (Fig. 7B). Therefore, there may be a requirement for protein kinase activity both during HFS and for 20 min after HFS.

Elucidating the critical period of protein kinase activity during LTP should be instrumental in determining the functional roles of kinases in producing LTP. There have been several studies demonstrating the regulation of NMDA receptors by PKC (Ben-Ari et al. 1992; Chen and Huang 1992), tyrosine kinases (Wang and Salter 1994), and phosphatases (Lieberman and Mody 1994; Wang et al. 1994). Muller and colleagues $(1990,1992)$ suggested that PKC has a role in regulating NMDA receptor activity during HFS and demonstrated that $\mathrm{H}-7$ and staurosporine attenuated the NMDA receptor-mediated component of EPSPs during high-frequency stimulation. However, a direct effect of $\mathrm{H}-7$ on the NMDA receptor was subsequently reported (Amador and Dani 1991). We chose to evaluate K-252a's effect on isolated NMDA receptor EPSPs in response to low-frequency stimulation in low $\mathrm{Mg}^{2+}$ media to avoid any potential effects the inhibitor may have on presynaptic facilitation mechanisms (Muller et al. 1988a, 1990). Additionally, NMDA-mediated EPSPs were large and easily measured using this protocol (Fig. 2). Because the NMDA receptor is highly permeable to $\mathrm{Ca}^{2+}$ (Mayer and Westbrook 1987), we feel confident that there is sufficient $\mathrm{Ca}^{2+}$ influx to activate protein kinases and modulate the NMDA receptor during low-frequency stimulation. We were unable to detect any affect of K-252a on NMDA receptor-mediated EPSPs at concentrations used to block LTP and inhibit PDBuinduced potentiation. In addition, K-252a applied after HFS significantly attenuated LTP, indicating that its ability to block LTP induction is attributable to actions downstream of NMDA receptor activation. Protein kinase activity may play a role in regulating NMDA receptor activity during LTP induction as suggested previously (Ben-Ari et al. 1992); however, this regulation may be frequency dependent. Nevertheless, our results suggest that there is an additional role of protein kinases after
HFS and NMDA receptor activation that is involved in the molecular pathways ultimately responsible for LTP expression.

Previous studies (Kauer et al. 1988; Muller et al. 1988b) suggested that one role of protein kinases during LTP may be to phosphorylate the $\alpha$-amino-3-hydroxy-5-methyl-4-isoxazolepropionic acid (AMPA) subtype of glutamate receptors. Receptor sensitivity to iontophoretically applied AMPA increases following LTP induction (Davies et al. 1989), and regulation of AMPA receptors by CaMKII and PKA has been demonstrated (Greengard et al. 1991; Wang et al. 1991; Tan et al. 1994). AMPA sensitivity increases slowly ( 15 min postHFS), remains elevated for the duration of LTP, and is blocked by the protein kinase inhibitor K-252b (Davies et al. 1989; Reymann et al. 1990). The time course of this phosphorylation-dependent increase in AMPA sensitivity is consistent with a critical period of protein kinase activity observed in our studies. Because protein synthesis is also required during the early phase of LTP (within 15 min after HFS; Stanton and Sarvey 1984; Otani et al. 1989), protein kinase activity may also facilitate the translation of new proteins (Hershey 1990) and/or modulate cytoskeletal dynamics (Nixon and Sihag 1991; Avila et al. 1994) that may contribute to lasting cellular and synaptic changes responsible for LTP expression.

Recent evidence indicates that synaptic stimulation activates $\mathbf{4} \mathbf{4 2}$ mitogen-activated protein $\mathbf{k i -}$ nase (MAPK) with a time course similar to the proposed critical period for LTP. By modulating spontaneous synaptic activity in neuronal cultures with extracellular $\mathrm{Ca}^{2+}$ and tetrodotoxin (TTX), Murphy et al. (1994) observed that constitutive MAPK activity increased slowly ( $10 \mathrm{~min}$ to maximal levels) with synaptic stimulation and decreased gradually (20 min to return to baseline) after the addition of TTX. MAPK must be phosphorylated on tyrosine and threonine residues to become constitutively active, which is mediated by a PKC-regulated activator kinase (Stratton et al. 1989). In contrast, CaMKII activation was rapid $(10 \mathrm{sec})$ and decayed to baseline within $3 \mathrm{~min}$ after TTX treatment. These results provide an example in which synaptic activity stimulates protein kinase activity with a slow time course. Although the relationships between the mechanisms underlying spontaneous synaptic transmission and LTP are unclear, MAPK could be activated through a protein kinase cascade during LTP and could represent a convergent point of tyrosine and

$$
\text { ….... }
$$


serine/threonine protein kinase pathways that are both required for LTP induction (O'Dell et al. 1991).

In summary, these results provide an estimate of the critical period of protein kinase activity required for LTP induction. LTP induction was most sensitive to protein kinase inhibition early (5-20 min) after HFS. These results suggest that critical phosphorylation events for LTP occur during the first 20 min after induction stimuli and ongoing protein kinase activity is not required during the later (30-80 min) stages of LTP. Increasing evidence indicates that phosphorylated substrates (e.g., B-50; Gianotti et al. 1992; and AMPA receptor; Davies et al. 1989) and new proteins (Otani et al. 1992; Fazelli et al. 1993) are responsible for the maintenance and expression of LTP.

\section{Acknowledgments}

We thank R.J. Cormier and M.N. Waxham for helpful discussions and comments on this manuscript. This work was supported in part by National Institutes of Health grants NS 22452 and NS 32470 (P.T.K.) and Scholars Awards from the McKnight Foundation (M.D.M.).

The publication costs of this article were defrayed in part by payment of page charges. This article must therefore be hereby marked "advertisement" in accordance with 18 USC section 1734 solely to indicate this fact.

\section{References}

Amador, M. and J.A. Dani. 1991. Protein kinase inhibitor, $\mathrm{H}-7$, directly affects $\mathrm{N}$-methyl-D-aspartate receptor channels. Neurosci. Lett. 124: 251-255.

Avila, J. J. Dom'inguez, and J. D'iaz-Nido. 1994. Regulation of microtubule dynamics by microtubule-associated protein expression and phosphorylation during neuronal development. Int. J. Dev. Biol. 38: 13-25.

Ben-Ari, Y., L. Aniksztejn, and P. Bregestovski. 1992. Protein kinase $C$ modulation of NMDA currents: An important link for LTP induction. Trends Neurosci. 15: 333-339.

Bittar, P. and D. Muller. 1993. Time-dependent reversal of long-term potentiation by brief cooling shocks in rat hippocampal slices. Brain Res. 620: 181-188.

Bliss, T.V.P. and T. Lømo. 1973. Long-lasting potentiation of synaptic transmission in the dentate area of the anaesthetized rabbit following stimulation of the perforant path. /. Physiol. 232: 331-356.

Bliss, T.V.P. and G.L. Collingridge. 1993. A synaptic model of memory: Long-term potentiation in the hippocampus. Nature 361: 31-39.

Browning, M.D. and E.M. Dudek. 1992. Activators of protein kinase $\mathrm{C}$ increase the phosphorylation of the synapsins at sites phosphorylated by CAMP-dependent and $\mathrm{Ca}^{2+} /$ calmodulin-dependent protein kinase in the rat hippocampal slice. Synapse 10: 62-70.

Chen, L. and L.Y.M. Huang. 1992. Protein kinase $C$ reduces $\mathrm{Mg}^{2+}$ block of NMDA-receptor channels as a mechanism of modulation. Nature 356: 521-523.

Cleveland, D.W., S.G. Fischer, M.W. Kirschner, and U.K. Laemmli. 1977. Peptide mapping by limited proteolysis in SDS and analysis by gel electrophoresis. J. Biol. Chem. 252: 1102-1106.

Collingridge, G.L., S.J. Kehl, and H. McLennan. 1983. Excitatory amino acids in synaptic transmission in the Schaffer collateral-commissural pathway of the rat hippocampus. I. Physiol. 334: 33-46.

Corradetti, R., A.M. Pugliese, and N. Ropert. 1989. The protein kinase $C$ inhibitor

1-(5-isoquinolinesulphonyl)-2-methylpiperazine $(\mathrm{H}-7)$ disinhibits CA1 pyramidal cells in rat hippocampal slices. $\mathrm{Br}$. J. Pharmacol. 98: 1376-1382.

Davies, S.N., R.A. Lester, K.G. Reymann, and G.L. Collingridge. 1989. Temporally distinct pre-and post-synaptic mechanisms maintain long-term potentiation. Nature 338: $500-503$.

Denny, J.B., J. Polan-Curtain, S. Rodriquez, M.J. Wayner, and D.L. Armstrong. 1990. Evidence that protein kinase M does not maintain long-term potentiation. Brain Res. 534: 201-208.

Dunwiddie, T. and G. Lynch. 1978. Long-term potentiation and depression of synaptic responses in the rat hippocampus: Localization and frequency dependency. I. Physiol. 276: 353-367.

Fazelli, M.S., J. Corbet, M.J. Dunn, A.C. Dolphin, and T.V.P. Bliss. 1993. Changes in protein synthesis accompanying long-term potentiation in the dentate gyrus. J. Neurosci. 13: 1346-1353.

Fukanaga, K., L. Stoppini, E. Miyamoto, and D. Muller. 1993. Long-term potentiation is associated with an increased activity of $\mathrm{Ca}^{2+}$ /calmodulin-dependent protein kinase. J. Biol. Chem. 268: 7863-7867.

Gianotti, C., M.G. Nunzi, W.H. Gispen, and R. Corradetti. 1992. Phosphorylation of the presynaptic protein B-50 (GAP-43) is increased during electrically induced long-term potentiation. Neuron 8: 843-848.

Greengard, P., J. Jen, A.C. Nairn, and C.F. Stevens. 1991. Enhancement of the glutamate response by CAMP-dependent protein kinase in hippocampal neurons. Science 253: 1135-1138.

Hashimoto, S. 1988. K-252a, a potent protein kinase inhibitor, blocks nerve growth factor-induced neurite

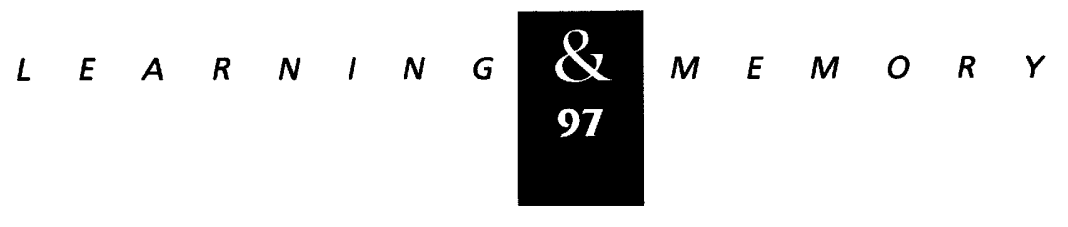




\section{Huber et al.}

outgrowth and changes in the phosphorylation of proteins in PC12h cells. J. Cell Biol. 107: 1531-1539.

Hashimoto, S., T. Nakayama, T. Teramoto, Y. Kato, T. Watanabe, M. Kinoshita, K. Tsukamoto, K. Tokunaga, K. Kurokawa, S. Nakanishi, Y. Matsuda, and Y. Nonomura. 1991. Potent and preferential inhibition of $\mathrm{Ca}^{2+} /$ calmodulin-dependent protein kinase II by K252a and its derivative, KT5926. Biochem. Biophys. Res. Commun. 181: 423-429.

Hershey, J.W. 1990. Overview: Phosphorylation and translation control. Enzyme 44: 17-27.

Hill, H.D. and J.G. Straka. 1988. Protein determination using bicinchoninic acid in the presence of sulfhydryl reagents. Anal. Biochem. 170: 203-208.

Huang, Y-Y., P.A. Colley, and A. Routtenberg. 1992. Postsynaptic then presynaptic protein kinase $C$ activity may be necessary for long-term potentiation. Neuroscience 49: 819-827.

Huttner, W.B. and P. Greengard. 1979. Multiple phosphorylation sites in protein I and their differential regulation by cyclic AMP and calcium. Proc. Natl. Acad. Sci. 76: 540-2-5406.

Kase, H., K. Iwahashi, and Y. Matsuda. 1986. K-252a, a potent inhibitor of protein kinase $C$ from microbial origin. I. Antibiot. 39: 1059-1065.

Kauer, J.A., R.C. Malenka, and R.A. Nicoll. 1988. A persistent postsynaptic modification mediates long-term potentiation in the hippocampus. Neuron 1: 911-917.

Kikkawa, U., A. Kishimoro, and Y. Nishizuka. 1989. The protein kinase $C$ family: Heterogeneity and its implications. Annu. Rev. Biochem. 58: 31-44.

Kishimoto, A., N. Kajikawa, M. Shiota, and Y. Nishizuka. 1983. Proteolytic activation of calcium-activated, phospholipid-dependent protein kinase by calcium-dependent neutral protease. J. Biol. Chem. 258: 1156-1164.

Klann, E., S.J. Chen, and J.D. Sweatt. 1993. Mechanism of protein kinase $C$ activation during the induction and maintenance of long-term potentiation probed using a selective peptide substrate. Proc. Natl. Acad. Sci. 90: $8337-8341$.

Leahy, J.C. and M.L. Vallano. 1991. Differential effects of isoquinolinesulfonamide protein kinase inhibitors on CA1 responses in hippocampal slices. Neuroscience 44: 361-370.

Lieberman, D.N. and I. Mody. 1994. Regulation of NMDA channel function by endogenous $\mathrm{Ca}^{2+}$-dependent phosphatase. Nature 369: 235-239.

Lin, J.W., M. Sugimori, R.R. Llinas, T.L. McGuiness, and P. Greengard. 1990. Effects of synapsin I and

calcium/calmodulin-dependent protein kinase II on spontaneous neurotransmitter release in the squid giant synapse. Proc. Natl. Acad. Sci. 87: 8257-8261.

Lisman, J. 1994. The CaM kinase II hypothesis for the storage of synaptic memory. Trends Neurosci. 17: 406-412.

Llinas, R.R., T.L. McGuiness, C.S. Leonard, M. Sugimori, and P. Greengard. 1985. Intraterminal injection of synapsin I or calcium/calmodulin-dependent protein kinase II alters neurotransmitter release. Proc. Natl. Acad. Sci. 82: 3035-3039.

Lynch, G., J. Larson, S. Kelso, G. Barrionuevo, and F. Schottler. 1983. Intracellular injections of EGTA block induction of hippocampal long-term potentiation. Nature 305: 719-721.

Malenka, R.C. 1989. Postsynaptic factors control the duration of synaptic enhancement in area CA1 of the hippocampus. Neuron 6: 53-60.

Malenka, R.C., D.V Madison, and R.A. Nicoll. 1986. Potentiation of synaptic transmission in the hippocampus by phorbol esters. Nature 321: 175-177.

Malenka, R.C., J.A. Kauer, D.J. Perkel, M.D. Mauk, P.T. Kelly, R.A. Nicoll, and M.N. Waxham. 1989. An essential role for postsynaptic calmodulin and protein kinase activity in long-term potentiation. Nature 340: 554-557.

Malenka, R.C., B. Lancaster, and R.S. Zucker. 1992. Temporal limits on the rise in postsynaptic calcium required for the induction of long-term potentiation. Neuron 9: $121-128$.

Malinow, R., D.V. Madison, and R.W. Tsien. 1988. Persistent protein kinase activity underlying long-term potentiation. Nature 335: 820-824.

Malinow, R., H. Schulman, and R.W. Tsien. 1989. Inhibition of postsynaptic PKC or CaMKII blocks induction but not expression of LTP. Science 245: 862-866.

Matthies, H., T. Behnisch, H. Kase, H. Matthies, and K.G. Reymann. 1991. Differential effects of protein kinase inhibitors on pre-established long-term potentiation in rat hippocampal neurons in vitro. Neurosci. Lett. 121: 259-262.

Mayer, M.L. and G.L. Westbrook. 1987. Permeation and block of $N$-methyl-D-aspartic acid receptor channels by divalent cations in mouse cultured central neurones. $/$. Physiol. 394: 501-527.

Meffert, M.K., K.D. Parfitt, V.A. Doze, G.A. Cohen, and D.V. Madison. 1991. Protein kinases and long-term potentiation. Ann. N.Y. Acad. Sci. 627: 2-9.

Miller S.G. and M.B. Kennedy. 1986. Regulation of brain type II $\mathrm{Ca}^{2+} /$ calmodulin-dependent protein kinase by autophosphorylation: $\mathrm{A} \mathrm{Ca}^{2+}$ triggered molecular switch. Cell 44: 861-870.

Muller, D., J. Turnbull, M. Baudry, and G. Lynch. 1988a.

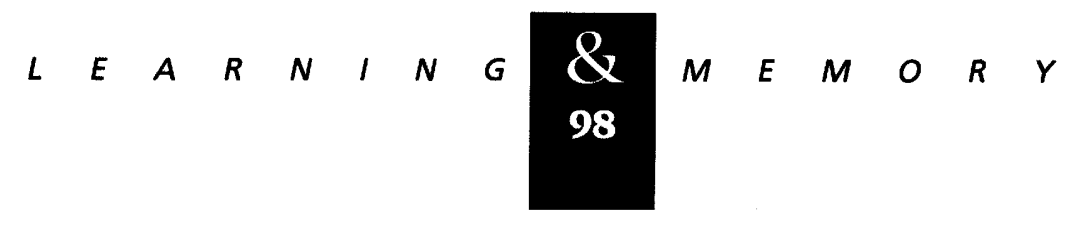


Phorbol ester-induced synaptic facilitation is different than long-term potentiation. Proc. Natl. Acad. Sci.

85: $6997-7000$.

Muller, D., M. Joly, and G. Lynch. 1988b. Contributions of quisqualate and NMDA receptors to the induction and expression of LTP. Science 242: 1694-1697.

Muller, D., P.A. Buchs, Y. Dunant, and G. Lynch. 1990. Protein kinase $C$ activity is not responsible for the expression of long-term potentiation in hippocampus. Proc. Natl. Acad. Sci. 87: 4073-4077.

Muller, D., P. Bittar, and H. Boddeke. 1992. Induction of stable long-term potentiation in the presence of the protein kinase $C$ antagonist staurosporine. Neurosci. Lett. 135: 18-22.

Müller, W. and J.A. Connor. 1991. Dendritic spines as individual neuronal compartments for synaptic $\mathrm{Ca}^{2+}$ responses. Nature 354: 73-76.

Murphy, T.H., L.A. Blatter, R.V. Bhat, R.S. Fiore, W.G. Wier, and J.M. Baraban. 1994. Differential regulation of calcium/calmodulin-dependent protein kinase II and p42 MAP kinase activity by synaptic transmission. J. Neurosci. 14: 1320-1331.

Nixon, R.A. and R.K. Sihag. 1991. Neurofilament phosphorylation: A new look at regulation and function. Trends Neurosci. 14: 501-506.

O'Dell, T.J. and E.R. Kandel. 1994. Low-frequency stimulation erases LTP through an NMDA receptor-mediated activation of protein phosphatases. Learn. Mem. 1: 129-139.

O'Dell, T.J., E.R. Kandel, and S.G.N. Grant. 1991. Long-term potentiation in the hippocampus is blocked by tyrosine kinase inhibitors. Nature 353: 558-560.

Otani, S., C.J. Marshall, W.P. Tate, G.V. Goddard, and W.C. Abraham. 1989. Maintenance of long-term potentiation in rat dentate gyrus requires protein synthesis but not messenger RNA synthesis immediately post-tetanization. Neuroscience 28: 519-526.

Otani, S., M.-P. Roisin-Lallemand, and Y. Ben-Ari. 1992. Enhancement of extracellular protein concentration during long-term potentiation in the rat hippocampal slice. Neuroscience 47: 265-272.

Regehr, W.G., J.A. Connor, and D.W. Tank. 1989. Optical imaging of calcium accumulation in hippocampal pyramidal cells during synaptic activation. Nature 341: 533-536.

Reymann, K.G., K. Schulzeck, H. Kase, and H. Matthies. 1988. Phorbol ester-induced hippocampal long-term potentiation is counteracted by inhibitors of protein kinase $C$. Exp. Brain Res. 71: 227-230.

Reymann, K.G., S.N. Davies, H. Matthies, and G.L. Collingridge. 1990. Activation of a K-252b-sensitive protein kinase is necessary for a post-synaptic phase of long-term potentiation in area CA1 of rat hippocampus. Eur. J. Neurosci. 2: 481-486.

Robinson, P.J., J.P. Liu, W. Chen, and T. Wenzel. 1993. Activation of protein kinase $C$ in vitro and in intact cells or synaptosomes determined by acetic acid extraction of MARCKS. Anal. Biochem. 210: 172-178.

Rosahl, T.W., M. Geppert, D. Spillane, J. Herz, R.E. Hammer, R.C. Malenka, and T.C. Sudhof. 1993. Short-term synaptic plasticity is altered in mice lacking synapsin I. Cell 75: 661-670.

Rüegg, U.T. and G.M. Burgess. 1989. Staurosporine, K-252 and UCN-01: Potent but nonspecific inhibitors of protein kinases. Trends Pharmacol. Sci. 10: 218-220.

Sacktor, T.C., P. Osten, H. Valsamis, X. Jiang, M.U. Naik, and $E$. Sublette. 1993. Persistent activation of the $\zeta$ isoform of protein kinase $C$ in the maintenance of long-term potentiation. Proc. Natl. Acad. Sci. 90: 8342-8346.

Stanton, P.K. and J.M. Sarvey. 1984. Blockade of long-term potentiation in rat hippocampal CA1 region by inhibitors of protein synthesis. J. Neurosci. 4: 3080-3088.

Stratton, K.R., P.F. Worley, R.L. Huganir, and J.M. Baraban. 1989. Muscarinic agonist and phorbol esters increase tyrosine phosphorylation of 40 kilodalton protein in hippocampal slices. Proc. Natl. Acad. Sci. 86: 2498-2501.

Sudhof, T.C., A.J. Czernik, H.T. Kao, K. Takei, P.A. Johnston, A. Horiuchi, S.D. Kanazir, M.A. Wagner, M.S. Perin, P. DeCamilli, and P. Greengard. 1989. Synapsins: Mosaics of shared and individual domains in a family of synaptic vesicle phosphoproteins. Science 245: 1472-1480.

Tamaoki, T., H. Nomoto, I. Takahashi, Y. Kato, M. Morimoto, and F. Tomita. 1986. Staurosporine, a potent inhibitor of phospholipid/ $/ \mathrm{Ca}^{2+}$ dependent protein kinase. Biochem. Biophys. Res. Commun. 135: 397-402.

Tan, S.-E., R.J. Wenthold, and T.R. Soderling. 1994. Phosphorylation of AMPA-type glutamate receptors by calcium/calmodulin-dependent protein kinase $\mathrm{II}$ and protein kinase $C$ in cultured hippocampal neurons. J. Neurosci. 14: 1123-1129.

Wang, J.H. and D.P. Feng. 1992. Postsynaptic protein kinase $\mathrm{C}$ essential to induction and maintenance of long-term potentiation in the hippocampal CA1 region. Proc. Natl. Acad. Sci. 89: 2576-2580.

Wang, L.-Y., M.W. Salter, and J.F. MacDonald. 1991. Regulation of kainate receptors by CAMP-dependent protein kinase and phosphatases. Science 253: 1132-1134.

Wang, L.-Y., B.A. Orser, D.L. Brautigan, and J.F. MacDonald. 1994. Regulation of NMDA receptors in cultured hippocampal neurons by protein phosphatases 1 and 2A. Nature 369: 230-232.

Wang, Y.T. and M.W. Salter. 1994. Regulation of NMDA

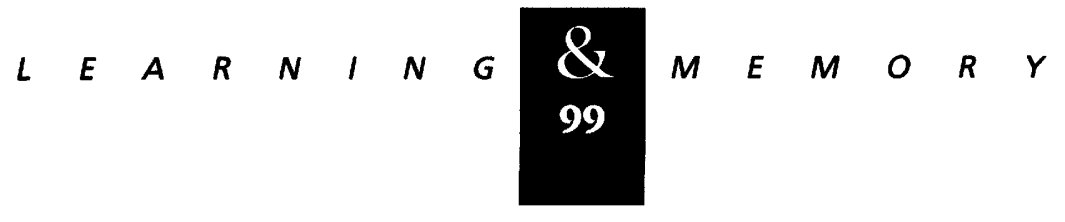




\section{Huber et al.}

receptors by tyrosine kinases and phosphatases. Nature 369: 233-235.

Waxham, M.N., R.C. Malenka, P.T. Kelly, and M.D. Mauk. 1993. Calcium/Calmodulin-dependent protein kinase II regulates hippocampal synaptic transmission. Brain Res. 609: 1-8.

Wu, W.C.-S., S.I. Walaas, and P. Greengard. 1982.

Calcium/phospholipid regulates phosphorylation of a $\mathrm{Mr}$

" $87 \mathrm{~K}$ " substrate protein in brain synaptosomes. Proc. Natl. Acad. Sci. 79: 5249-5253.

Yip, R.K. and P.T. Kelly. 1989. In situ phosphorylation in hippocampal tissue slices. J. Neuroscience 9: 3618-3630.

Received January 30, 1995; accepted in revised form May 12, 1995. 


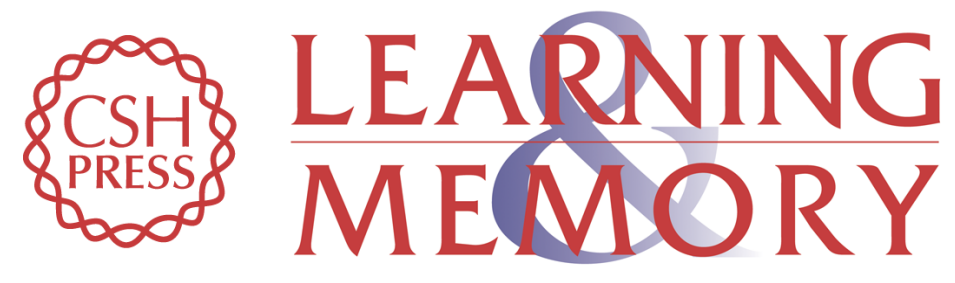

\section{A critical period of protein kinase activity after tetanic stimulation is required for the induction of long-term potentiation.}

K M Huber, M D Mauk, C Thompson, et al.

Learn. Mem. 1995, 2:

Access the most recent version at doi:10.1101//m.2.2.81

References This article cites 75 articles, 23 of which can be accessed free at: http://learnmem.cshlp.org/content/2/2/81.full.html\#ref-list-1

License

Email Alerting Receive free email alerts when new articles cite this article - sign up in the box at the Service top right corner of the article or click here. 